\title{
Towards the Development of a Targeted Albumin-Binding Radioligand for Theranostic Applications: Synthesis, Radiolabelling and Preliminary In Vivo Studies
}

\author{
Cathryn Helena Stanford Driver, ${ }^{[a, b]}$ Thomas Ebenhan, ${ }^{[a]}$ Zoltan Szucs, ${ }^{[c]}$ Mohammed lqbal \\ Parker, ${ }^{[\mathrm{d}]}$ Jan Rijn Zeevaart, ${ }^{*[a]}$ and Roger Hunter ${ }^{[\mathrm{b}]}$
}

[a] Dr. C.H.S, Driver; Prof. T. Ebenhan; Prof. JR. Zeevaart

South African Nuclear Energy Corporation, Radiochemistry and NuMeRI PreClinical Imaging Facility

Elias Motsoaledi Street, R104 Pelindaba,

North West, 0240

South Africa

*E-mail: janrijn.zeevaart@necsa.co.za

[b] Prof. R. Hunter

Department of Chemistry

University of Cape Town

Rondebosch, Cape Town, 7700

South Africa

[c] Dr. Z. Szucs

MTA Atomki,

Debrecen, Bem Square 18/c, 4026,

Hungary

[d] Prof. M.I. Parker

Department of Medical Biochemistry and Institute for Infectious Disease and Molecular Medicine,

University of Cape Town Medical School,

Observatory, Cape Town, 7925

South Africa

Supporting information for this article is given via a link at the end of the document.

\begin{abstract}
The compound named 4-[10-(4-(2,5-dioxo-2,5-dihydro1H-pyrrol-1-yl)butanamido)decyl]-11-[10-( $\beta$,D-glucopyranos-1-yl)-1oxodecyl]-1,4,8,11-tetraazacyclotetradecane-1,8-diacetic acid is a newly synthesised molecule capable of binding in vivo to albumin to form a bioconjugate given the name, GluCAB (glucose-chelatoralbumin bioconjugate). GluCAB is proposed as a theranostic agent for prospective oncological applications and works on a dualtargeting principle of tumour localization through the "enhanced permeability and retention (EPR) effect" and glucose metabolism. GluCAB-maleimide-1 was synthesized in five consecutive steps with an overall yield of $11 \%$ via sequential regioselective, distal $\mathrm{N}$ functionalisation of a cyclam template with a tether containing a synthetically-derived $\beta$-glucoside followed by a second linker to incorporate a maleimide for albumin-binding. GluCAB-amine-2 was successfully labelled with Copper-64 and converted post-labelling to $\left[{ }^{64} \mathrm{Cu}\right] \mathrm{Cu}-\mathrm{GluCAB}-\mathrm{maleimide-1}$. The biodistribution of $\left[{ }^{64} \mathrm{Cu}\right] \mathrm{Cu}-$ GluCAB-maleimide-1 in healthy mice using microPET/CT imaging and ex vivo gamma analysis indicated a prolonged biological half-life with excretion through the hepatobiliary system. This initial evaluation paves the way for further investigation into the tumour targeting potential of $\left[{ }^{64} \mathrm{Cu}\right] \mathrm{Cu}-\mathrm{GluCAB}-$ maleimide-1.
\end{abstract}

\section{Introduction}

The principle of targeted cancer diagnosis or treatment involves the use of drug-delivery systems that improve the efficiency of drug uptake by the tumour. ${ }^{[1]}$ In designing a selective cancer targeting agent, it is necessary therefore to understand cancercell tumourigenesis and the tumour micro-environment. Tumours develop as a result of cancerous cells that are fast-growing and which over-express many cell-surface receptors, each associated with the provision of metabolites for cell growth and division. ${ }^{2]}$ New cancer diagnostics or therapeutics can be designed to have a high affinity for one of these up-regulated cancer cell-surface receptors leading to the compound's accumulation within the tumour cell ('Active' targeting). Active targeting ligands include monoclonal antibodies (mAbs) as well as antibody fragments, proteins, peptides, and small molecules that target a number of different antigens and receptors.

The tumour microenvironment is characterized by interstitial hypertension, hypoxia, low extracellular $\mathrm{pH}$, decreased lymphatics, and the angiogenesis of blood vessels with defective architecture. ${ }^{[3,4]}$ These abnormalities result in the leakage of blood plasma components into tumour tissue, where they are then retained. The latter explains why certain macromolecular drugs (> $40 \mathrm{kDa}$ for the renal excretion threshold ${ }^{[5]}$ ) preferentially accumulate within the tumour, a phenomenon noted by Matsamura and Maeda and termed the "enhanced permeability and retention (EPR) effect". ${ }^{6]}$ New cancer diagnostics or therapeutics can be also be designed to exploit the tumour microenvironment and the EPR effect ('passive' targeting). ${ }^{7,8]}$ Passive targeting agents include polymers, liposomes, nanoparticles, and some larger proteins. Active and passive targeting can be used in combination to improve the efficacy of drug delivery to the tumour site and uptake by the cancer cells. A theranostic radiopharmaceutical contains a radionuclide and can provide both a diagnostic as well as a therapeutic option depending on the radioisotope that is coordinated to it. ${ }^{[9]}$ The design of a targeted theranostic radiopharmaceutical for oncological purposes requires careful consideration of the physical decay properties of the radioisotope to be used, the specific in vivo targeting mechanism for the tumour and the clearance of the compound from other tissues so that the 
radioisotope, the targeting molecule, the chelating agent and the linker are all compatible with each other for maximum in vivo stability. ${ }^{[10]}$ Taking these factors into consideration, the general aim of this project was therefore to develop a new dual-target theranostic bioconjugate greater than $40 \mathrm{kDa}$ in size, radiolabelled with a therapeutic or a diagnostic isotope.

The ligand proposed for development as a theranostic radiopharmaceutical is shown in Figure $\mathbf{1}$ and was designed to attach to a larger passive targeting agent such as albumin to form a bioconjugate. This bioconjugate will be referred to as GluCAB (Glucose-Chelator-Albumin-Bioconjugate). GluCABmaleimide-1 (1) comprises a distally $\mathrm{N}$-di-functionalised cyclam chelating agent, functionalised through sequential $\mathrm{N}$-alkylation with a glucose moiety and a maleimide, each contained at the end of a polymethylene linker, as well as two carboxymethylene groups at the other cyclam nitrogens for radionuclide coordination and stability. This ligand is theoretically capable of being labelled with a radionuclide, and thereafter, the expectation was that the covalent addition of circulating, endogenous human serum albumin $(\mathrm{HSA})^{[11]}$ to the maleimide via Michael addition of a cysteine thiol group, would furnish the active bioconjugate.

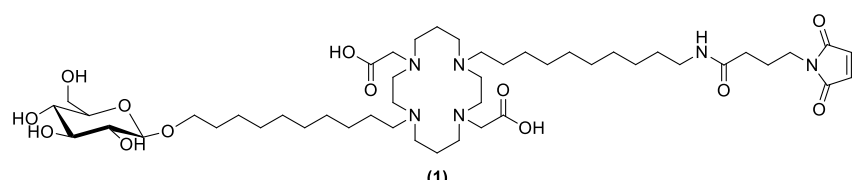

Figure 1. The structure of GluCAB-maleimide-1

The protein carrier and passive targeting agent selected, human serum albumin (HSA), has a molecular weight of $66.5 \mathrm{kDa}$ (large enough for the EPR effect), is the most abundant serum protein (35-50 $\mathrm{g} / \mathrm{l}, 50-60 \%)$, and has a half-life of around 19 days, making it very stable in context. ${ }^{[12,13]}$ HSA has been used as a protein carrier in the development of new targeting agents ${ }^{[11]}$, such as FDA-approved Abraxane (paclitaxel-albumin nanoparticle) for the treatment of breast cancer ${ }^{[14]}$; and for improving the biological half-life, pharmacokinetics and overall therapeutic efficacy of radiopharmaceuticals, such as ${ }^{177} \mathrm{Lu}$ DOTA-TATE and ${ }^{177}$ Lu-PSMA. ${ }^{[15-17]}$ Small molecule binding to albumin can either be covalent - a Michael addition of the thiol of cysteine-34 to a maleimide ${ }^{[11,13,15]}$ - or reversible, noncovalent - physical interactions of 4 -( $p$-iodophenyl)butyric acid and Evans Blue (azo dye) with the protein. ${ }^{[16]}$

The function of the glucose moiety is two-fold; firstly, the glucose increases the hydrophilicity and therefore the aqueous solubility of the ligand and secondly, it plays a supportive role as an active targeting agent. The selection of glucose as an active targeting agent was based on the expression of glucose transporters (GLUT) on the cell surface, since these have been shown to be up-regulated on cancer cells owing to their high glucose requirement for provision of energy and metabolic needs. ${ }^{[18,19]}$ The most widely used radiopharmaceutical that exploits this property for cancer diagnosis is $\left[{ }^{18} \mathrm{~F}\right]$ Fluorodeoxyglucose $\left(\left[{ }^{18} \mathrm{~F}\right] \mathrm{FDG}\right)^{[20]}$ and based on this same principle of GLUT and glycolysis targeting, a few other glucose analogue targeting agents have also been developed. ${ }^{[21-24]}$ Most recently, a glucose-targeted probe $(1380 \mathrm{~g} / \mathrm{mol})$ for photoacoustic and fluorescent imaging was proven to have cell uptake through GLUT. ${ }^{[25]}$
The tetra-amine macrocycle, cyclam, was identified as the chelating agent, as it is cheap and readily available and has been widely used in a number of compounds for medicinal applications, including PET imaging and for the complexation of a number of different metals with very good in vivo stability. ${ }^{\text {[26-29] }}$ The diagnostic isotope selected was copper-64 $\left(\mathrm{t}_{1 / 2}=12.7 \mathrm{~h}\right)$, which decays though positron emission (17\%, $655 \mathrm{keV})$, electron capture/Auger-emissions (44\%) and beta emission $(39 \%, 573 \mathrm{keV}) .{ }^{[30,31]}$ Copper-64 and its other isotopes $\left({ }^{60} \mathrm{Cu}\right.$, ${ }^{61} \mathrm{Cu},{ }^{62} \mathrm{Cu},{ }^{67} \mathrm{Cu}$ ) have been shown to complex to many chelating agents with high stability, including to a number of derivatised cyclam macrocycles, and have been used in many radiopharmaceutical applications. ${ }^{[30-34]}$ While copper-64 and the other copper isotopes are mostly used for diagnostic purposes, copper-67 $\left(\mathrm{t}_{1 / 2}=61.8 \mathrm{~h}\right)$ emits beta $\left(\beta^{-}\right)$particles of $580 \mathrm{keV}$ (100\%) (penetration range of $2.1 \mathrm{~mm}$ ) with gamma rays of 92 and $184 \mathrm{keV}$ being useful for therapeutic applications. Copper64 and copper-67 together form a theranostic isotope pair that can be used for diagnosis and therapy. ${ }^{[31,35]}$ This ${ }^{64} \mathrm{Cu} /{ }^{67} \mathrm{Cu}$ theranostic is a favourable option for a theranostic agent, however, the limitation with using copper-67 is its high production cost and limited availability. Recently, copper-64 has been investigated as a single theranostic isotope for both its proven diagnostic use and potential therapeutic capabilities (beta and Auger-emissions). ${ }^{[30]}$

The development of GluCAB as a potentially new targeted ${ }^{64} \mathrm{Cu} /{ }^{67} \mathrm{Cu}$-theranostic radiopharmaceutical was planned in a phased approach. The first phase encompassed the ligand synthesis and radiolabelling while the subsequent phases phase 2 and 3 - would involve in vitro stability along with in vivo metabolism in healthy animals, and in vivo tumour targeting in a xenograft animal model, respectively. Herein is described the synthesis of the desired GluCAB-maleimide-1 followed by techniques for radiolabelling of this compound with copper-64 (Phase 1). In addition, Phase 2, for a preliminary understanding of the in vivo characteristics of $\left[{ }^{64} \mathrm{Cu}\right] \mathrm{Cu}-\mathrm{GluCAB}$-maleimide-1 and its albumin-binding potential, is also reported through the use of small animal PET/CT imaging followed by post mortem biodistribution .

\section{Results and Discussion}

GluCAB-maleimide-1 was synthesized according to the retrosynthetic analysis shown in Scheme 1 . The synthesis required the sequential $\mathrm{N}$-alkylation of di-(tert-butyl acetate) cyclam (5) using tethered glycosyl bromide (4)(active targeting moiety) followed by Boc-protected amine (6) as functionalised linkers and subsequent functional group inter-conversions, and will be discussed in the text. The preferred order of alkylation between linkers (4 and 6 ) and the challenges faced during synthesis will further be discussed.

\section{Synthesis of Linkers}

Synthesis of the C-1, O-alkylated glycosyl bromide (4) is shown in Scheme 2A. It involved using the one-pot glycosylation method of Murakami et al. ${ }^{[36]}$ in which perbenzoylated glucose (8) was converted, almost exclusively, to its a-glycosyl iodide (9) using iodine and hexamethyldisilazane (in situ producer of 


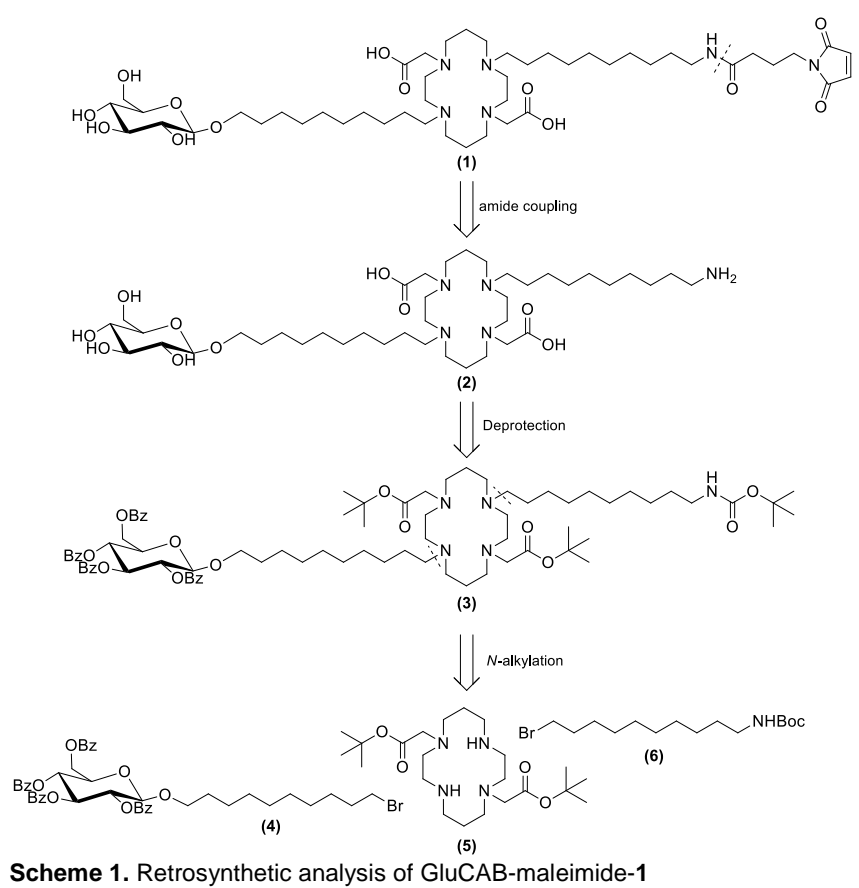

iodotrimethylsilane $\left.\left(\mathrm{Me}_{3} \mathrm{Sil}\right)\right)$ under Lewis acid catalysis with zinc chloride. The formation of the glycosyl iodide $a$-anomer using $\mathrm{Me}_{3} \mathrm{Sil}$ has been previously proven and studied mechanistically. ${ }^{[37]}$ lodide (9) was not purified but substituted directly with 10-bromodecanol via activation with 1 eq. of $\mathrm{ZnCl}_{2}$ to form the $\beta$-anomer of glycoside (4) (59\% yield over the two steps).

A)

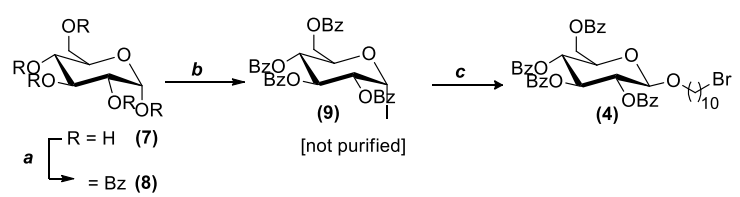

B)

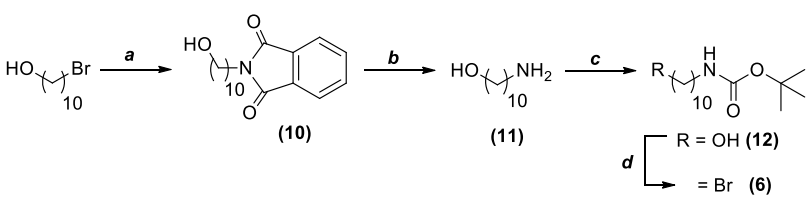

Scheme 2. Synthesis of linkers - glycosyl bromide (4) and Boc-protected amine (6) A) (a) $\mathrm{BzCl}$, pyridine, $0^{\circ} \mathrm{C}-\mathrm{RT}$, (89\%), (b) $\mathrm{I}_{2},\left(\mathrm{Me}_{3} \mathrm{Si}\right)_{2}, \mathrm{ZnCl}_{2}$ $\mathrm{CH}_{2} \mathrm{Cl}_{2}, 16 \mathrm{~h}, \mathrm{RT}$ (c) 10-bromodecanol, $\mathrm{ZnCl}_{2}$, Molecular sieves $4 \mathrm{~A}, \mathrm{CH}_{2} \mathrm{Cl}_{2}$ (59\% over steps a and b). B) (a) Potassium phthalimide, DMF, $100{ }^{\circ} \mathrm{C}, 20 \mathrm{hrs}$ $(97 \%)$ (b) Hydrazine hydrate, EtOH, reflux, $24 \mathrm{hrs}(88 \%)$, (c) (Boc) $)_{2} \mathrm{O}$, DCM:MeOH 4:1, 3 hrs, (89\%), (d) $\mathrm{CBr}_{4}, \mathrm{PPh}_{3}, \mathrm{DCM},(92 \%)$

The $\beta$-glycoside (4) formed diastereoselectively via exclusive $\beta$ addition of 10-bromodecanol onto the intermediate oxocarbenium ion (from iodide ionization with the Lewis acid $\mathrm{ZnCl}_{2}$ ), due to neighbouring group participation by the 2-benzoyl group on the a-face. A C-10 alkyl chain was used for the linker in order to minimise steric interference between the targeting agent-chelator and the biomolecule carrier (albumin) during biological targeting. In a previous study that investigated the effects of the linkers of albumin-binding compounds on the in vitro and in vivo properties, it was found that an alkyl linker performed slightly better than a larger, more hydrophilic PEG linker. ${ }^{[38]}$ The synthesis of the second linker, Boc-protected amine (6), for alkylative attachment to the chelator, was achieved according to a series of standard functional group conversion reactions as indicated in Scheme 2B. 10-amino-1decanol (11) was obtained through a Gabriel reaction by first treatment of 10-bromo-1-decanol with potassium phthalimide followed by subsequent hydrolysis of the phthalimide (10) formed with hydrazine hydrate. The resultant amine was then protected as a $t$-butyl carbamate (12) followed by conversion of the hydroxyl group to bromide (6) under Appel conditions. The yields of each step were high (> 85\%) throughout.

\section{Functionalisation of Cyclam}

Distal, sequential dialkylation of cyclam (5) with bromide-linkers (4) and (6) required prior protection of two of the distal nitrogens of cyclam with alkoxycarbonylmethylene groups. However, alkylation studies with $t$-butyl bromoacetate and a base resulted in a complex mixture containing six alkylated cyclam compounds, amongst which were three difunctionalised regioisomers that included the desired 1,8-N,N'-di-functionalised product. The ratio of mono, di and trisubstituted products could be slightly manipulated by adjusting the equivalents of $t$-butyl bromoacetate but a mix of the products was still obtained. The maximum amount of disubstituted product could be obtained by the addition of 3 equivalents of the $t$-butyl bromoacetateover 6 hrs in increments of 0.5 , using potassium carbonate as base (2.5 equiv). These three regioisomers could, with difficulty, then be purified from each other using column chromatography $\left(\mathrm{CH}_{2} \mathrm{Cl}_{2}: \mathrm{MeOH} 5: 1\right)$, but the yield of each $\left(1,4-N, N^{\prime}=16 \% ; 1,8-\right.$ $N, N^{\prime}=41 \% ; 1,11-N, N^{\prime}=$ not determined ) was very low.

A method developed by Pandya et. al. ${ }^{[39]}$ (Scheme 3) reported the selective synthesis of cyclam (5) starting from 1,4,8,11tetraazatricyclo[9.3.1.14,8 ${ }^{4,8}$ hexadecane (tricyclic bis-aminal cyclam (13)) via a quaternary ammonium salt intermediate. Cyclam (13), synthesized by alkylation with formaldehyde (2 eq), comprises the bridging of two of the six-membered rings in cyclam as aminals in stable chair conformations, which makes the outward-facing lone pairs more available for alkylation (at positions 1 and 8). Following quaternization, the methylene bridges are base-hydrolysed to afford symmetrical transdisubstituted cyclam (5).

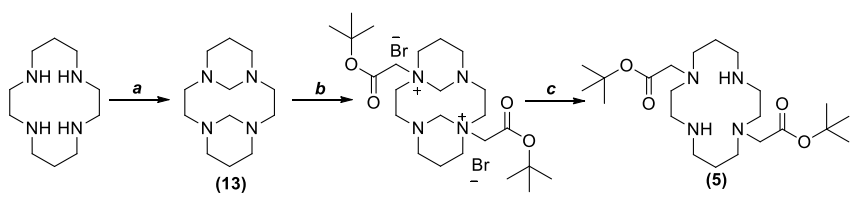

Scheme 3. Selective synthesis of trans-disubstituted cyclam (5) (Pandya et .al. ${ }^{[39]}$ ) (a) Formaldehyde (2 eq), $\mathrm{H}_{2} \mathrm{O}, \mathrm{RT}, 2 \mathrm{~h}$ (b) $\mathrm{BrCH}_{2} \mathrm{CO}_{2}{ }^{t}-\mathrm{Bu}$ (4 eq), $\mathrm{MeCN}$, $60^{\circ} \mathrm{C}, 24 \mathrm{~h}$ (c) $3 \mathrm{M} \mathrm{NaOH}, \mathrm{RT}, 3 \mathrm{~h}$

Following the method ${ }^{[39]}$ as described, 4 eq of $t$-butyl bromoacetate was used in the alkylation of $(13)$ at $60^{\circ} \mathrm{C}$, but the quaternary di-ammonium salt intermediate could not be obtained as a precipitate as described. Chromatographic investigations resulted in isolation of the mono-alkylated cyclam (14) $(65 \%$ yield) in which the aminal bridge at the site of alkylation was deprotected in situ via the mechanism proposed below in Scheme 4. The water involved was proposed to originate from the recrystallisation of the tricyclic bis-aminal (13) from a mixture of THF and water, as a crystal structure obtained for (13) in- 
house indicated three water molecules to be part of the crystal lattice.

(A)

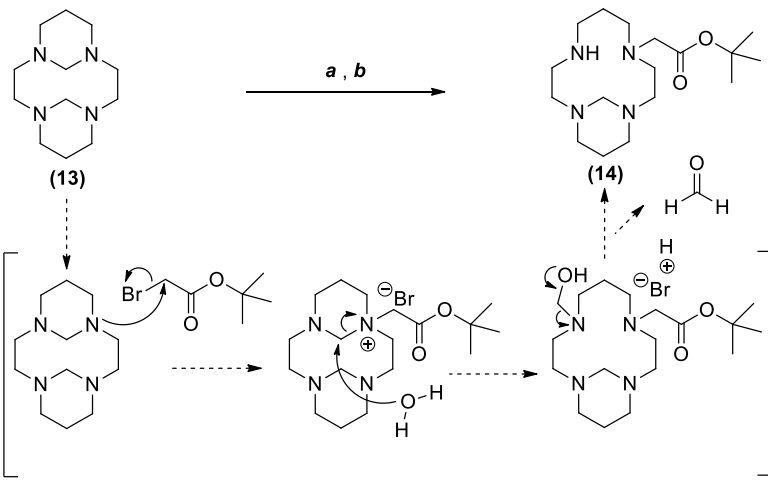

Scheme 4. Synthesis and proposed mechanism for mono-alkylation of tricyclic bis-aminal cyclam A) (a) $\mathrm{BrCH}_{2} \mathrm{CO}_{2}{ }^{t}-\mathrm{Bu}\left(4 \mathrm{eq}\right.$ ), $\mathrm{MeCN}, 60^{\circ} \mathrm{C}, 48 \mathrm{hrs}$, (b) 3 $\mathrm{M} \mathrm{NaOH}, 16 \mathrm{~h},(65 \%)$; B) the proposed mechanism for formation of monoalkylated (14).

In a further attempt to obtain the $1,8-N, N^{\prime}$-di-t-butyl ester quaternary ammonium salt, (13) was reacted with excess $t$-butyl bromoacetate $(6 \mathrm{eq})$ in acetonitrile for 5 days at $70^{\circ} \mathrm{C}$, after which, before $\mathrm{NaOH}$ hydrolysis, some crude solid product could be obtained by precipitation from diethyl ether. Upon recrystallisation of this crude material from acetonitrile with a small percentage $(<5 \%)$ of methanol, a colourless solid product (20\% yield) was obtained. ${ }^{1} \mathrm{H}$ and ${ }^{13} \mathrm{C}$ NMR spectroscopic analysis of this solid in $\mathrm{D}_{2} \mathrm{O}\left(10 \mathrm{mg} \mathrm{K}_{2} \mathrm{CO}_{3}\right.$ added to the NMR tube to ensure the free base form of the compound), (see Supporting Information Figure S1) identified this product as the 1,8-N,N'-disubstituted cyclam (5) in accordance with the ${ }^{1} \mathrm{H}$ and ${ }^{13} \mathrm{C}$ NMR spectral data reported in the literature. ${ }^{[40]}$ Briefly, ${ }^{1} \mathrm{H}$ NMR indicated the required peaks for the cyclam macrocycle and the two $t$-butyloxycarbonylmethylene groups distally: one methylene singlet $(4 \mathrm{H}, 3.30 \mathrm{ppm})$; one $t$-butyl group $(18 \mathrm{H}, 1.43$ ppm); multiplets at $1.72 \mathrm{ppm}(4 \mathrm{H}), 2.60 \mathrm{ppm}(4 \mathrm{H}), 2.69 \mathrm{ppm}$ $(8 \mathrm{H})$ and $2.74 \mathrm{ppm}(4 \mathrm{H})$ for the symmetrically equivalent methylene groups of a distally disubstituted cyclam macrocycle. Similarly, ${ }^{13} \mathrm{C}$ data showed only 5 cyclam resonances. The data for 1,8-N,N'-cyclam (5) was also distinguishable ${ }^{[40]}$ from the previously isolated and identified 1,4-N,N'-regioisomer (see Supporting Information, Figure S2), as well as the 1,11-isomer, based on symmetry considerations. The removal of the bridges could again potentially be explained by the presence of water in the reaction. Although low-yielding, the procedure was found to be reproducible, furnished high-purity $(5)$ and could be scaled up. GluCAB-amine-2 was then synthesized via standard alkylation and deprotection strategies as shown in Scheme $\mathbf{5}$.

Briefly, cyclam (5) was alkylated using glycoside (4) to form (15) $(58 \%)$, followed by alkylation using carbamate (6) to yield cyclam (3) (74\%). Both alkylations used potassium carbonate in acetonitrile with heating. Alkylation with glycoside (4) was performed first so as to introduce UV activity into thestructure, which assisted with chromatography and isolation. Similarly, the order of deprotecting the protecting groups of cyclam (3) (benzoate esters, tert-butyl esters and tert-butyl carbamate) was completed in a way that ensured the easiest purification. Deprotection of the benzoate esters of (3) to yield (16) was completed under nucleophilic conditions using sodium methoxide, towards which the tert-butyl esters and carbamate

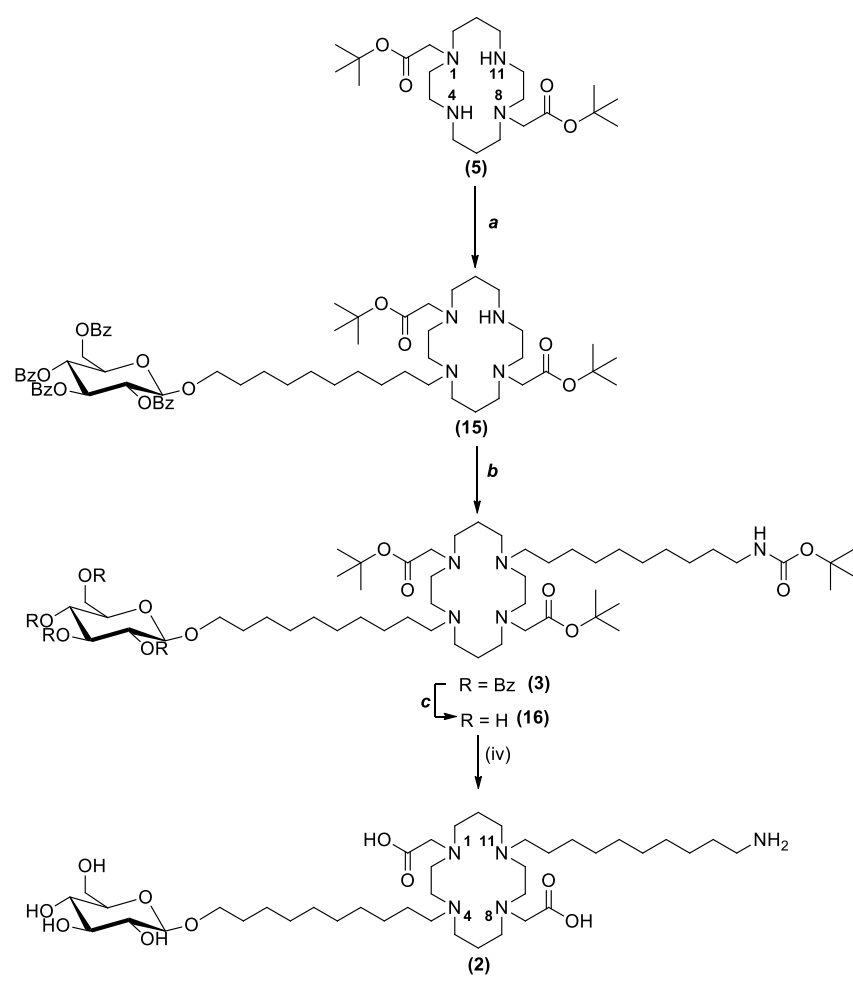

Scheme 5. Synthesis of GluCAB-amine-2 (a) Glycosyl bromide (4), $\mathrm{K}_{2} \mathrm{CO}_{3}$, $\mathrm{MeCN}, 60{ }^{\circ} \mathrm{C}, 16 \mathrm{~h}(58 \%)$, (b) carbamate $6, \mathrm{~K}_{2} \mathrm{CO}_{3}, \mathrm{MeCN}, 80{ }^{\circ} \mathrm{C}, 16 \mathrm{~h}(74 \%)$, (c) $\mathrm{NaOMe}, \mathrm{MeOH}, 1 \mathrm{~h}(71 \%)$, iv) TFA: $\mathrm{CH}_{2} \mathrm{Cl}_{2}$ (1:1), $16 \mathrm{~h}$ (69\%)

were stable. Compound (16) could be purified using silica-based column chromatography. Further Boc- and tert-butyl ester deprotection of (16) was carried out under acidic conditions using TFA to afford GluCAB-amine-2 (2), for which full characterization was carried out (see the Supplementary Information). The glycosyl functionality of GluCAB-amine-2 was found to be stable under the acidic Boc-deprotection conditions using TFA, in which only a very small amount $(<10 \%)$ of byproduct was fortunately observed. The purification using column chromatography of free GluCAB-amine-2 (silica gel 60 , $\mathrm{DCM}: \mathrm{MeOH}: \mathrm{NH}_{4} \mathrm{OH}$ 7:2.5:0.5), however, proved challenging as a result of polarity, which caused the compound to adhere to the stationary phase. Consequently, while the reaction conversion seemed high ( $90 \%$ according to TLC), the reaction yield was fairly low $(<50 \%)$. The stationary phase was then changed to an Alumina- $\mathrm{N}$ matrix in which elution with $\mathrm{DCM}: \mathrm{MeOH}: \mathrm{NH}_{4} \mathrm{OH}$ (8:1.7:0.3; 7:2.5:0.5; 6.5:3:0.5) removed the impurities, after which the product could be eluted with $40 \% \mathrm{H}_{2} \mathrm{O}$ in $\mathrm{MeOH}$. Once concentrated, the product was desalted on a solid phase extraction (SPE) $\mathrm{C} 18$ light cartridge using water, and eluted from the cartridge using $50 \% \mathrm{MeOH}$ in $\mathrm{H}_{2} \mathrm{O}$. The product was dried under an air stream, re-dissolved in water $(1 \mathrm{~mL})$, frozen and lyophilised to yield a colourless solid powder pellet. The yield of GluCAB-amine-2 obtained from this purification was improved to $69 \%$, leading to an overall yield, over the four steps from cyclam 5 , of $21 \%$.

Having two linkers in the $N 4$ and the $N 11$ position of GluCABamine-2 ensured placement of the glucose targeting moiety distally away from the albumin carrier that would eventually be attached to the terminal amine position. This structure also placed the two coordinating carboxylic acid groups opposite to each other to form a more stable, octahedral type geometry when coordinating the radioisotope ${ }^{[40]}$ 


\section{Maleimide Insertion}

The concept of a GluCAB bioconjugate requires the in vivo binding of the synthesised ligand to albumin. Towards this endthe primary amine of GluCAB-amine-2 was converted into a maleimide as GluCAB-maleimide-1, thereby providing a Michael acceptor for capture of the free Cys-34 thiol group of albumin as described previously. ${ }^{[11,13,15]}$ GluCAB-maleimide-1 was synthesised through a mixed anhydride peptide coupling strategy, which initially envisaged coupling of a tethered maleimido-carboxylic acid synthon, 4-maleimidobutyric acid (17), with the terminal amine of GluCAB-amine-2 using ethyl chloroformate and $\mathrm{Et}_{3} \mathrm{~N}$ for carboxyl activation of (17). However, in a model reaction between a model amine and the activated derivative of 4-maleimidobutyric acid (17), (see the Supplementary information Scheme S1), regioselectivity issues arose involving competition in the $S_{N} A c$ substitution with the amine and the two carbonyl groups of the mixed anhydride, which led to the coupling strategy being revised.

The revised, and ultimately successful strategy, first investigated the $\mathrm{N}$-hydroxysuccinimide (NHS) activation of 4maleimidobutyric acid using DIC as coupling agent in $\mathrm{CH}_{2} \mathrm{Cl}_{2}$ to form the 4-maleimidobutyric acid NHS-ester (18) (72\%), (Scheme 6), which was then reacted with 10-amino-decanol (11) in a model experiment (Supporting Information, Scheme S2). This reaction was carried out in a mildly basic aqueous medium (0.01 M PBS, $\mathrm{pH} 7.4$ ), which formed the desired maleimide-amide coupled product in an isolated yield of $54 \%$. The advantage of this NHS-coupling method was that an aqueous medium was more suitable for miscibility and reaction of the highly polar GluCAB-amine-2. However, equally, this method suffered from sensitivity of the NHS-ester (18) towards hydrolysis in an aqueous medium, especially at an acidic $(\mathrm{pH}<7)$ or basic $\mathrm{pH}(\mathrm{pH}>8)$. The NHS-ester (18) was found to be most stable when dissolved in an organic solvent, which resulted in optimized reaction conditions involving the addition of small increments of the NHS-ester in DMF to the amine in a $0.01 \mathrm{M}$ PBS buffer $(\mathrm{pH} \mathrm{7.4)}$ at room temperature.

The success of this model coupling reaction allowed for its successful application to GluCAB-amine-2 which was reacted with NHS-ester (18) (dissolved in DMF) for $2 \mathrm{~h}$ (Scheme 6) in the same basic conditions (0.01 M PBS, $\mathrm{pH}$ 7.4) as for the model study. The conversion from starting material to a single product could be observed on TLC. This product was very soluble in water because of its high polarity and needed to be purified using a Sep-Pak C-18 Plus light cartridge as described in the methods. During purification, it appeared that some of the maleimide product was degrading (hydrolysing) and only approximately $50 \%$ of GluCAB-maleimide-1 product was isolated. HPLC-MS analysis of (1) after $1 \mathrm{~h}$ in water indicated two peaks $(8.5$ and $9.0 \mathrm{~min})$ in the UV-trace $(210 \mathrm{~nm})$. The 8.5 min peak $(m z[+H]=973.6)$ proved to be the maleamic acid compound (1a) (Scheme 6) while the 9.0 min peak $(m z[+H]=$ 955.6) corresponded to the GluCAB-maleimide-1.

Overall, the maleimide functionality proved to be very sensitive towards hydrolysis to the open maleamic acid form, especially under acidic conditions $(\mathrm{pH}<6.5)$, at higher temperatures, and in the presence of nucleophiles. This sensitivity, therefore, had to be carefully considered during any proposed radioisotope complexation, as maleimide hydrolysis during this process and subsequent administration of the maleamic acid compound in vivo was feared would have a serious effect on the compound's biological efficacy due to inefficient albumin-binding.

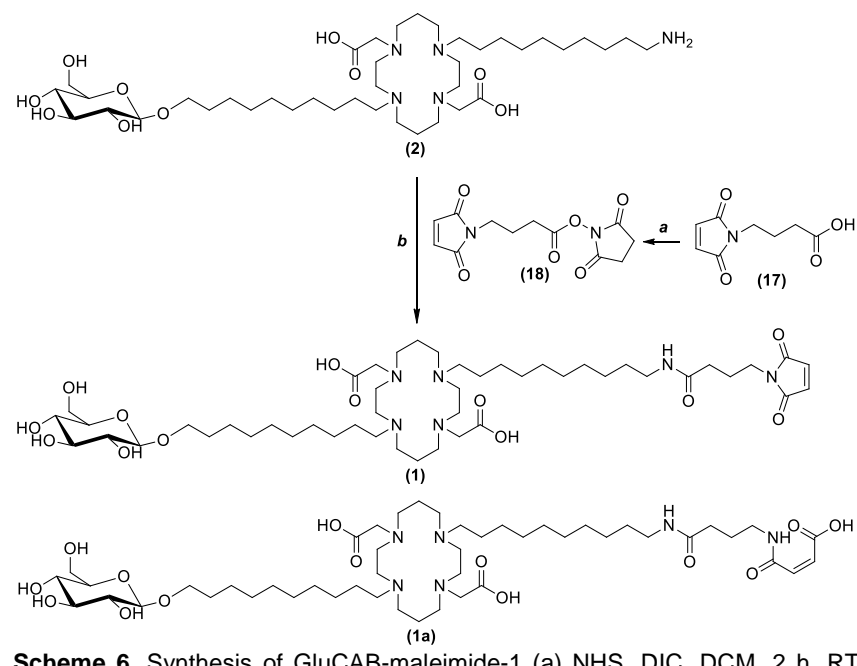

Scheme 6. Synthesis of GluCAB-maleimide-1 (a) NHS, DIC, DCM, 2 h, RT (72\%) (b) $0.01 \mathrm{M} \mathrm{PBS}, \mathrm{pH} 7.4,1 \mathrm{~h}, \mathrm{RT}$ (1) $(55 \%)(\mathrm{mz}[+\mathrm{H}]=955.6)$ (hydrolysed maleamic acid product $1 \mathrm{a}(\mathrm{mz}[+\mathrm{H}]=973.6))$.

\section{Radiolabelling}

Preparation of $\left.{ }^{64} \mathrm{Cu}\right] \mathrm{CuCl}_{2}$ and Radiolabelling of GluCABamine-2. Copper-64 was obtained through irradiation of natural $\mathrm{CuO}\left(69.17 \%\right.$ abundance of $\left.{ }^{63} \mathrm{Cu}\right)$ in the SAFARI-1 research reactor at Pelindaba, Necsa via the ${ }^{63} \mathrm{Cu}(\mathrm{n}, \mathrm{\gamma}){ }^{64} \mathrm{Cu}$ nuclear reaction. ${ }^{[41]}$ This method produces copper-64 of a lower specific activity as compared to the more widely used method of enriched ${ }^{64} \mathrm{Ni}$-target irradiation with low energy protons (11-14 $\left.\mathrm{MeV} ;{ }^{64} \mathrm{Ni}(\mathrm{p}, \mathrm{n}){ }^{64} \mathrm{Cu}\right),{ }^{[42,43]}$ but it is less expensive and more easily accessible than the cyclotron-produced copper-64. A $\left[{ }^{64} \mathrm{Cu}\right] \mathrm{CuCl}_{2}$ solution was prepared with a specific (molar) activity of $1450 \mathrm{GBq} / \mathrm{g}(115 \mathrm{MBq} / \mu \mathrm{mol})$.

As previously mentioned copper-64 is known to form kinetically inert and thermodynamically stable complexes with a variety of cyclam chelators. These complexes form under a wide range of reaction conditions that need to be compatible with the functional groups attached to the macrocycle. Earlier, we had established that the maleimide functionality of GluCABmaleimide-1 had revealed a high sensitivity towards hydrolysis under acid conditions and in aqueous solutions at high temperatures. Therefore, in pursuit of the ${ }^{64} \mathrm{Cu}$-labelled GluCAB radioligand, complexation of GluCAB-amine-2 with copper-64 was investigated to first determine optimal conditions, with the possible intention to incorporate the maleimide subsequently.

To this end, GluCAB-amine-2 was reacted with the prepared $\left[{ }^{64} \mathrm{Cu}\right] \mathrm{CuCl}_{2}(115 \mathrm{MBq} / \mu \mathrm{mol} ; 0.33 \mathrm{eq})$ in a $0.1 \mathrm{M} \mathrm{NH}_{4} \mathrm{OAc}$ solution at different $\mathrm{pH}$ 's, temperatures, and incubation times. An overview of the experimental series is given in the Supporting Information Table S1. The best labelling efficiency (LE) for complexation of GluCAB-amine-2 with copper-64 was found to be $98 \%$ with an average LE of $95 \%$ under the same conditions irrespective of radioisotopic activity concentration. Radio-HPLC analysis of the reaction indicated that the free $\left.{ }^{[6} \mathrm{Cu}\right] \mathrm{CuCl}_{2}$ was only minimally retained on the reverse-phase HPLC column, eluting with a retention time of 3-4 min, while the slightly less hydrophilic $\left[{ }^{64} \mathrm{Cu}\right] \mathrm{Cu}-\mathrm{GluCAB}$-amine-2 eluted at around $11.5 \mathrm{~min}$. The LE decreased significantly $(\mathrm{p}<0.05)$ upon incubation at higher $\mathrm{pH}$ values $(\mathrm{pH} 5(86 \%)$ and $9(80 \%))$, for 
shorter reaction times $(20(61 \%)$ and $10 \mathrm{~min}(39 \%))$ or at lower temperatures (45 $(5 \%), 70(29 \%)$ or $\left.80^{\circ} \mathrm{C}(81 \%)\right)$.

The temperature of the reaction had the most detrimental impact on the radiolabelling since at $45{ }^{\circ} \mathrm{C}$ hardly any complexation occurred $(<5 \%$ LE). Copper (II) is a medium hard/soft Lewis acid and forms strong bonds with the nitrogen of amino groups of macrocycles such as those in cyclam, especially when there are carboxylate pendant arms. ${ }^{[3,34]}$ The formation of these bonds; however, requires a large amount of energy for the metal ion to overcome its kinetic inertness and bind to the $\mathrm{N}$ - and $\mathrm{O}$ donors with dissociation from its chloride ligands to form an octahedral complex. ${ }^{[44]}$ The temperature, therefore, is crucial for providing enthalpy of activation. The $\mathrm{pH}$ of the reaction also had a slight effect on complex formation in which the best complexation being observed at $\mathrm{pH} 3.5$, while at $\mathrm{pH} 9$ the LE decreased by $15 \%$. A possible reason for this is that at the higher $\mathrm{pH}$ values, there are more negatively charged ions present in the reaction solution to compete for the positively charged copper ions, making the binding rate to the macrocycle slower and less efficient.

These optimised conditions (high temperature and low $\mathrm{pH}$ ) for radiolabelling of GluCAB-amine-2 with copper-64 preclude complex formation using GluCAB-maleimide-1 because of incompatibility with the maleimide functional group. The maleimide incorporation using NHS-ester (18) as described, would therefore need to occur post-labelling.

Post-labelling Conversion of $\left[{ }^{64} \mathrm{Cu}\right] \mathrm{Cu}$-GluCAB-amine-2 to $\left[{ }^{64} \mathrm{Cu}\right] \mathrm{Cu}$-GluCAB-maleimide-1. $\left[{ }^{64} \mathrm{Cu}\right] \mathrm{Cu}-\mathrm{GluCAB}$-amine-2 was converted to $\left[{ }^{64} \mathrm{Cu}\right] \mathrm{Cu}-\mathrm{GluCAB}$-maleimide- 1 by reaction with a 4 maleimidobutyric acid NHS-ester (18) for $1 \mathrm{~h}$ in $0.01 \mathrm{M}$ PBS at $\mathrm{pH} 7.4$ and an incubation temperature of $40^{\circ} \mathrm{C}$. Pleasingly, the maleimide product (retention time $=13.5 \mathrm{~min} ; 90 \%$ radiochemical purity; conversion of $93 \%$ ) proved to be stable in the PBS buffer during the reaction process with no noticeable hydrolysis of the maleimide to the maleamic acid (retention time $=12.5 \mathrm{~min}$ ) (Figure 2). The time required for the reaction and purification $(\sim 1.5-2 \mathrm{~h})$ was sufficiently lower than the half-life of copper-64 (12.7 h); thus, the process was suitable for a postlabelling conversion.

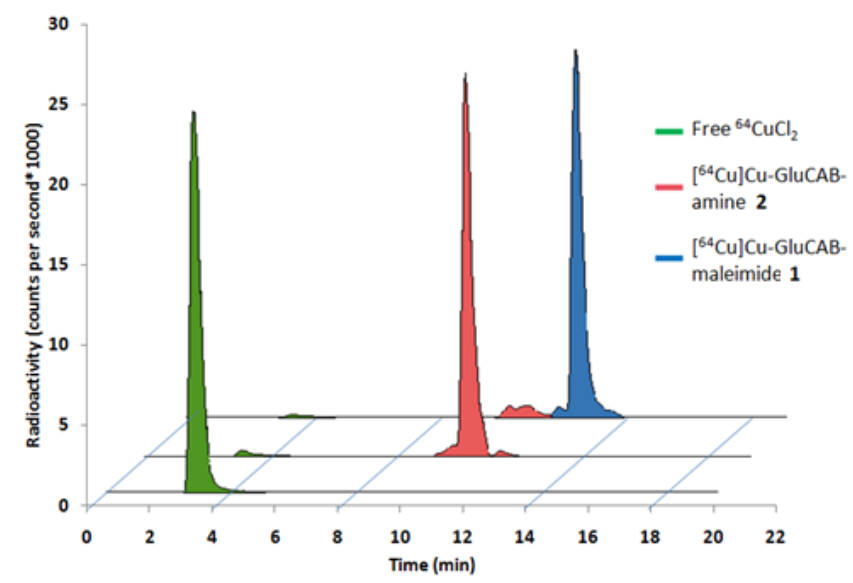

Figure 2. Radio-HPLC chromatograms of free $\left[{ }^{64} \mathrm{Cu}\right] \mathrm{CuCl}_{2}$ (green peak $-\mathrm{RT}=$ $3.4 \mathrm{~min}$ ); $\left[{ }^{64} \mathrm{Cu}\right] \mathrm{Cu}-\mathrm{GluCAB}$-amine-2 (pink peak, 97\% radiochemical purity)(RT $=11.5 \mathrm{~min}$ ) and post labeling conversion to $\left[{ }^{64} \mathrm{Cu}\right] \mathrm{Cu}-\mathrm{GluCAB}$-maleimide-1 (blue peak - 90\% radiochemical purity, 93\% conversion)(RT = $13.5 \mathrm{~min}$ ).

\section{In vitro Studies}

Stability Studies and Protein Binding of $\left[{ }^{64} \mathrm{Cu}\right] \mathrm{Cu}$-GluCABamine-2 and $\left[{ }^{64} \mathrm{Cu}\right] \mathrm{Cu}$-GIuCAB-maleimide-1. Preliminary stability studies in $0.01 \mathrm{M}$ PBS buffer were performed, firstly to test the tendency of the maleimide towards hydrolysis and secondly, to establish whether copper was lost from the chelator. For $\left[{ }^{64} \mathrm{Cu}\right] \mathrm{Cu}$-GluCAB-maleimide-1, it was found that approximately $14 \%$ of the maleimide had hydrolysed after $24 \mathrm{~h}$ (0.01 M PBS (pH 7.4); room temperature) (Supporting Information, Figure S3) with only a $1.5 \%$ re-occurrence in free copper-64 species.

Protein binding studies provide an indication of how well, if at all, a compound will bind to proteins in the blood, and especially to HSA, considering that this protein constitutes $60 \%$ of all serum proteins. Binding of the GluCAB compound to HSA was seen to be an essential part of the targeting mechanism and $\left[{ }^{64} \mathrm{Cu}\right] \mathrm{Cu}-$ GluCAB-maleimide-1 was designed in such a manner (maleimide functionality) that a high percentage of protein binding was anticipated. A protein binding study was therefore carried out comparing $\left[{ }^{64} \mathrm{Cu}\right] \mathrm{Cu}-\mathrm{GluCAB}$-maleimide-1 and $\left[{ }^{64} \mathrm{Cu}\right] \mathrm{Cu}-\mathrm{GluCAB}-\mathrm{amine-2}$ (no maleimide functionality), (Figure 3). The radioactivity present in the proteins (precipitated and centrifuged out from serum) was measured following incubation $(0,1,2$ and $24 \mathrm{~h})$ with each compound at $37^{\circ} \mathrm{C}$. Upon addition to the serum, $\left[{ }^{64} \mathrm{Cu}\right] \mathrm{Cu}$-GluCAB-maleimide-1 was immediately $85 \%$ protein bound which further increased to a maximum of $90 \%$ within $2 \mathrm{~h}$ that was sustained through to $24 \mathrm{~h}$. The small percentage that remained 'unbound' could be attributed to the nature of the radiolabelling process in which $3 \%$ radioactivity remained as free $\left[{ }^{64} \mathrm{Cu}\right] \mathrm{CuCl}_{2}$ and the residual as GluCABamine-2. Conversely, $\left[{ }^{64} \mathrm{Cu}\right] \mathrm{Cu}-\mathrm{GluCAB}$-amine-2 showed a very low $(30 \%)$ protein binding upon addition to the serum, which reached $50 \%$ protein binding after $24 \mathrm{~h}$. This can be considered non-specific protein association, as no maleimide group was present. Possible non-specific interactions included charge interactions (between the protonated amino group and carboxylic acid functionalities), hydrogen bonding, and other hydrophobic interactions (between ligand and serum protein). Subsequent to protein binding studies, serum stability studies were also completedfor both the $\left[{ }^{64} \mathrm{Cu}\right] \mathrm{Cu}$-GluCAB-maleimide-1 and the $\left[{ }^{64} \mathrm{Cu}\right] \mathrm{Cu}-\mathrm{GluCAB}$-amine-2. Radio-HPLC analysis indicated high stability of both ${ }^{64} \mathrm{Cu}$-complexes to de-metallation as well as ligand robustness at $37{ }^{\circ} \mathrm{C}$ over the $24 \mathrm{~h}$ since no degradation products or increase in the amount of free copper64 was observed (Supporting Information, Figure S4).

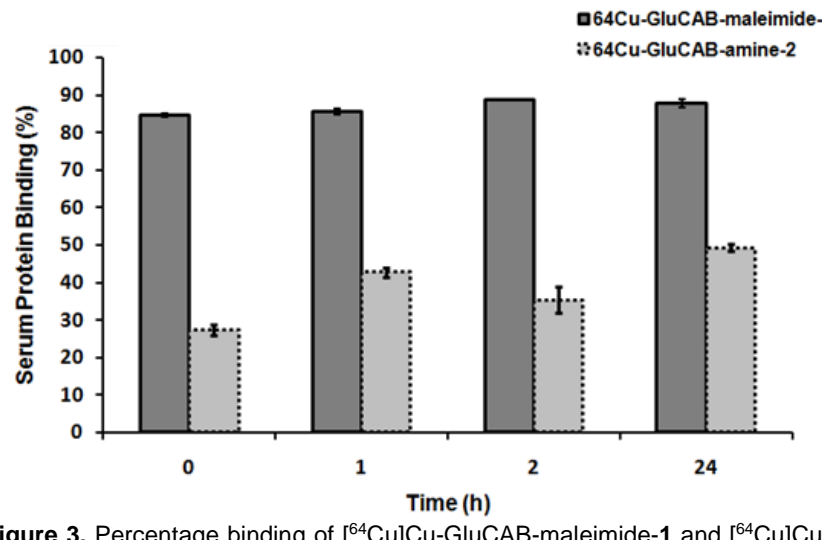

GluCAB-amine-2 to proteins in serum over a $24 \mathrm{~h}$ period at $37{ }^{\circ} \mathrm{C}$ (mean $\pm \mathrm{SD}$ $\mathrm{n}=3$ ) 


\section{In vivo Studies}

MicroPET/CT Imaging Studies in healthy Balb/c mice. The prospective capability of GluCAB for tumour targeting can only be evaluated in vivo since the first mechanism of uptake relies on binding of the GluCAB-maleimide-1 to albumin and extravasation into the tumour through the EPR effect, which necessitates a living biological system. Valuable understanding of the tracer administration, metabolism, excretion and biodistribution of the compound needed to be achieved before further actual tumour targeting studies in mice could be attempted. This concept of altered biodistribution of $\left[{ }^{64} \mathrm{Cu}\right] \mathrm{Cu}$ GluCAB-maleimide-1 (and consequently the GluCAB bioconjugate) was therefore determined in healthy Balb/c mice using microPET/CT imaging followed by post mortem radioanalysis of excised organs and tissue. This was compared to the behavior of two other compounds; $\left[{ }^{64} \mathrm{Cu}\right] \mathrm{Cu}-\mathrm{TETA}$ (negative control since rapid metabolism and excretion was anticipated) and $\left[{ }^{64} \mathrm{Cu}\right] \mathrm{Cu}-\mathrm{GluCAB}$-amine-2 (lacking the maleimide functionality; predicting a faster excretion rate despite non-specific serum protein binding). Similar compound concentrations of $\left[{ }^{64} \mathrm{Cu}\right] \mathrm{Cu}-\mathrm{TETA}(100 \mu \mathrm{L} ; 1.2 \pm 0.22 \mathrm{MBq} ; 39$ $\mathrm{nmol} / \mathrm{mouse}$ ), $\left[{ }^{64} \mathrm{Cu}\right] \mathrm{Cu}-\mathrm{GluCAB}-$ amine-2 (150 $\mu \mathrm{L} ; 5.6 \mathrm{MBq}, 31$ $\mathrm{nmol} /$ mouse) and $\left[{ }^{64} \mathrm{Cu}\right] \mathrm{Cu}$-GluCAB-maleimide-1 (100 $\mu \mathrm{L} ; 1.0 \pm$ $0.09 \mathrm{MBq}, 31 \mathrm{nmol} / \mathrm{mouse}$ ) were administered for comparison of the groups $(n=5)$; no adverse side effects were noted. Subsequently, microPET/CT imaging was conducted over a $24 \mathrm{~h}$ period for which maximum intensity projection (MIP) allowed for a visual comparison between the biodistribution of the three compounds (Figure 4).

The MIP images represent the expected $\left[{ }^{64} \mathrm{Cu}\right] \mathrm{Cu}$-TETA biodistribution (Figure 4A) as reported in literature ${ }^{[45]}$, which is dominated by a rapid tracer clearance from the blood pool and a major systemic clearance by way of renal excretion (i.e. high activity present only in the bladder within 1-2 $\mathrm{h}$ post injection). Furthermore, at $24 \mathrm{~h}$ post-injection (p.i), only minimal activity was still evident in the animal. By comparison, the $\left[{ }^{64} \mathrm{Cu}\right] \mathrm{Cu}$ GluCAB-amine-2 microPET/CT (Figure 4B) visualised the occurrence of activity within the hepatobiliary system, suggesting a different route of excretion compared to $\left[{ }^{64} \mathrm{Cu}\right] \mathrm{Cu}$ TETA. However; just as $\left[{ }^{64} \mathrm{Cu}\right] \mathrm{Cu}-\mathrm{TETA},\left[{ }^{64} \mathrm{Cu}\right] \mathrm{Cu}-\mathrm{GluCAB}-$ amine-2 had cleared early-on in significant amounts and within $24 \mathrm{~h}$ p.i negligible radioactivity concentration in all major organs (except for intestines) was observed. MIP images of the mice administered with $\left[{ }^{64} \mathrm{Cu}\right] \mathrm{Cu}$-GluCAB-maleimide-1 (Figure 4C) showed that this compound had a prolonged biological half-life and blood circulation as indicated by the high overall systemic activity (a blue colour in the image) and clear visibility of the heart even at $8 \mathrm{~h}$ p.i as compared to $\left[{ }^{64} \mathrm{Cu}\right] \mathrm{Cu}-\mathrm{GluCAB}-a m i n e-2$. These images also clearly indicated a high accumulation of radioactivity in the liver, intestines, and bladder from $1-8 \mathrm{~h}$ p.i. This activity was mostly cleared after $24 \mathrm{~h}$ but with some hepatic radioactivity activity still notable.

Further analyses included the image-guided quantification from volumes-of-interest (VOI), yielding standard uptake values (SUV $(\mathrm{g} / \mathrm{mL}))$; e.g. VOI and SUV indicative of the decay-corrected compound concentration in the heart muscle (representing blood pool) for each time point, allowing for an estimation of their biological half-life. The heart activity concerning $\left[{ }^{64} \mathrm{Cu}\right] \mathrm{Cu}$-TETA and $\left[{ }^{64} \mathrm{Cu}\right] \mathrm{Cu}-\mathrm{GluCAB}$-amine-2 calculated from the $1 \mathrm{~h}$ PET image was 0.02 and $0.04 \mathrm{~g} / \mathrm{mL}$, respectively.

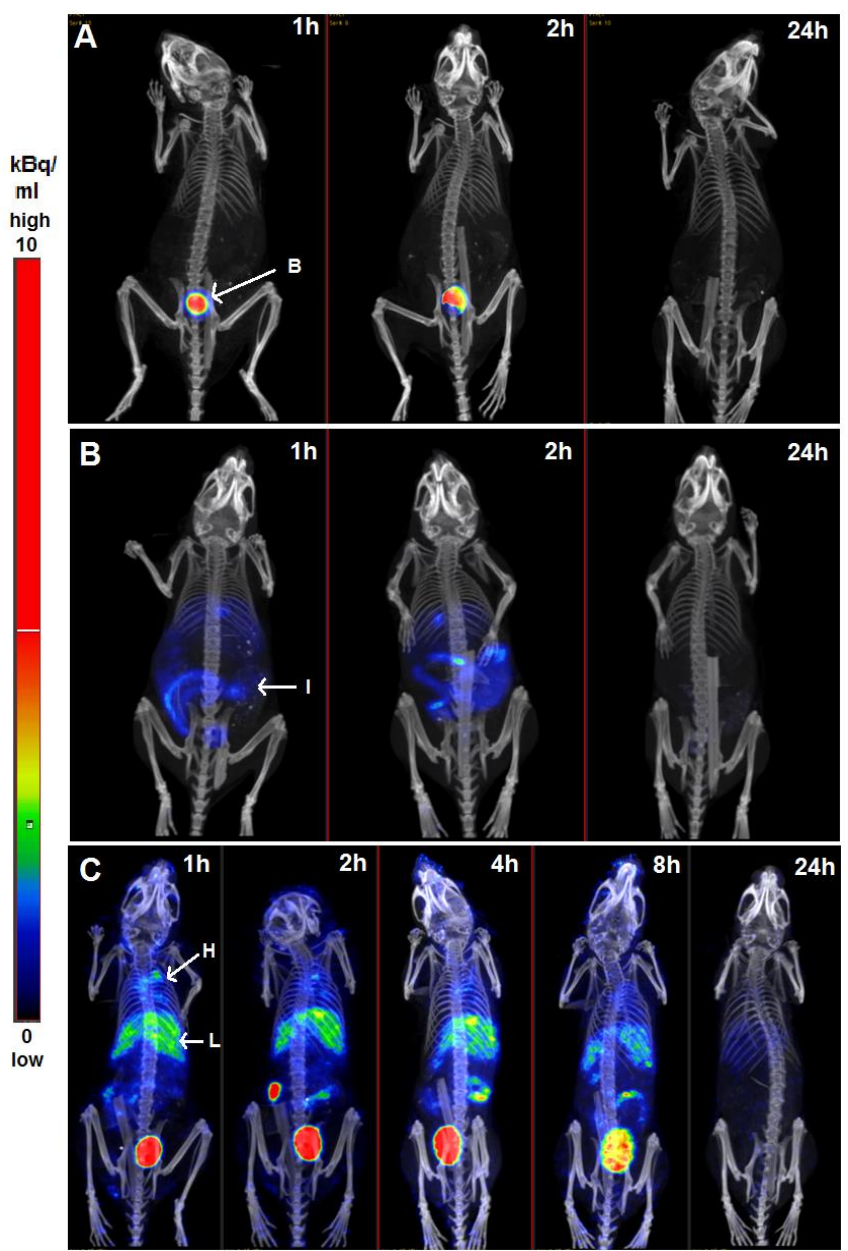

Figure 4. Maximum intensity projection microPET/CT images (anterior view) of BALB/c mice following injection with (A) $\left[{ }^{64} \mathrm{Cu}\right] \mathrm{Cu}-\mathrm{TETA},(\mathbf{B})\left[{ }^{64} \mathrm{Cu}\right] \mathrm{Cu}$ GluCAB-amine-2 and (C) $\left[{ }^{64} \mathrm{Cu}\right] \mathrm{Cu}-\mathrm{GluCAB}-m a l e i m i d e-1$. Image acquisition was done at 1, 2 and $24 \mathrm{~h}(\mathrm{~A} / \mathrm{B})$ and at 1, 2, 4, 8 and $24 \mathrm{~h}(\mathrm{C})$ post injection $(n=3)$. $B=$ bladder; $H=$ heart; $L=$ liver; $I=$ intestines. Normalised scale bar $0-10$ $\mathrm{kBq} / \mathrm{mL}$.

This was deemed fairly low and reflected the representation from the images. Therefore, the biological half-lives of these two compounds were assumed to be $<5 \mathrm{~min}$, but could not be exactly determined. However, analysis of the heart region for $\left[{ }^{64} \mathrm{Cu}\right] \mathrm{Cu}$-GluCAB-maleimide-1 $(1 \mathrm{~h}=1.44 \mathrm{~g} / \mathrm{mL})$ indicated the expected exponential decrease of the circulating activity over the $24 \mathrm{~h}$ period $(24 \mathrm{~h}=0.10 \mathrm{~g} / \mathrm{mL})$ in which the biological half-life was estimated about $6-8 \mathrm{~h}$. Other notable SUV for $\left[{ }^{64} \mathrm{Cu}\right] \mathrm{Cu}$ GluCAB-maleimide-1 included the liver ( $\max .2 .74 \mathrm{~g} / \mathrm{mL}$ at $1 \mathrm{~h}$ to $\min .0 .29 \mathrm{~g} / \mathrm{mL}$ at $24 \mathrm{~h}$ ) and intestines (max. $0.79 \mathrm{~g} / \mathrm{mL}$ at $4 \mathrm{~h}$ to $\min .0 .07 \mathrm{~g} / \mathrm{mL}$ at $24 \mathrm{~h}$ ).

According to current theories ${ }^{[46]}$ on drug metabolism, the most common routes of drug elimination is renal excretion (glomerular filtration of small, hydrophilic, non-protein bound drugs or tubular secretion of larger, protein-bound drugs); or hepatobiliary excretion (more lipophilic compounds). In the study of the metabolism and excretion of drug-radioisotope complexes, it has been noted that the clearance pathway, specifically of bifunctional chelate conjugates, is significantly influenced by the lipophilicity and net charge of the complex. ${ }^{[45]}$ The more lipophilic a complex is the higher the liver accumulation will be and the slower the systemic clearance. Similarly, a conjugate with a positively-charged complex exhibits slow excretion through the 
liver but conversely, a negatively-charged complex is more rapidly and efficiently cleared through the kidneys.

The routes of excretion noted from the MIP PET images for all three compounds are in line with the above mentioned aspects on compound metabolism and excretion. $\left[{ }^{64} \mathrm{Cu}\right] \mathrm{Cu}-\mathrm{TETA}$ is a relatively small, hydrophilic molecule with a net negative complex charge while $\left[{ }^{64} \mathrm{Cu}\right] \mathrm{Cu}-\mathrm{GluCAB}-m a l e i m i d e-1$ and $\left[{ }^{64} \mathrm{Cu}\right] \mathrm{Cu}$-GluCAB-amine-2 are more lipophilic with a neutral complex charge. As identified by the amount of activity in the specific organs involved with excretion (kidneys, bladder, liver, intestines), $\left[{ }^{64} \mathrm{Cu}\right] \mathrm{Cu}$-TETA was excreted through the renal system while $\left[{ }^{64} \mathrm{Cu}\right] \mathrm{Cu}$-GluCAB-maleimide-1 and $\left[{ }^{64} \mathrm{Cu}\right] \mathrm{Cu}$ GluCAB-amine-2 were eliminated to different extents via the hepatobiliary system.

Although $\left[{ }^{64} \mathrm{Cu}\right] \mathrm{Cu}-\mathrm{TETA}$ and $\left[{ }^{64} \mathrm{Cu}\right] \mathrm{Cu}-\mathrm{GluCAB}$-amine-2 have similar blood clearance rates, the difference between their excretion can potentially be explained by: 1) the difference in molecular weight of the compounds $(432.5 \mathrm{~g} / \mathrm{mol}$ versus 790.1 $\mathrm{g} / \mathrm{mol}$ ) making the smaller TETA compound more suitable for rapid glomerular filtration; 2) the difference in charge between the two complexes (negative versus neutral), which influences the hydrophilicity of the compounds; 3 ) the tethers (C-10aliphatic chains) attached to the chelator for $\left[{ }^{64} \mathrm{Cu}\right] \mathrm{Cu}-\mathrm{GluCAB}$ amine-2 that renders this compound more lipophilic and therefore prone to hepatobiliary metabolism; and 4) the nominal non-specific binding of $\left[{ }^{64} \mathrm{Cu}\right] \mathrm{Cu}$-GluCAB-amine-2 to serum proteins (as herein determined) that may provoke more hepatic involvement.

Similar to $\left[{ }^{64} \mathrm{Cu}\right] \mathrm{Cu}$-GluCAB-amine-2, $\quad\left[{ }^{64} \mathrm{Cu}\right] \mathrm{Cu}$-GluCABmaleimide-1, is a lipophilic and neutrally charged complex that shows metabolism through the liver but with the difference of having a tethered maleimido functional group. This study confirmed a markedly prolonged biological half-life of $\left[{ }^{64} \mathrm{Cu}\right] \mathrm{Cu}$ GluCAB-maleimide-1 (6 - $8 \mathrm{~h}$ ) compared to -amine-2 (<5 min). This may be sufficient proof of the effectiveness of the maleimide functionality for binding to albumin and therefore substantially extending an unwanted-short tracer residence time in the blood circulation. The albumin-binding of $\left[{ }^{64} \mathrm{Cu}\right] \mathrm{Cu}$ GluCAB-maleimide-1 in turn affected the rate of liver metabolism, which seemed markedly reduced as inferred from the prolonged and high accumulation of activity in the liver and intestines over the $24 \mathrm{~h}$ period. Albumin is known to be eliminated through renal $(6 \%)$, hepatobiliary $(10 \%)$ and other catabolic (84\%) mechanisms, ${ }^{[47]}$ and therefore the activity which was seen in the liver and intestines is not unexpected for a covalently bound GluCAB-albumin bioconjugate. While reversible albumin-binding allows for a slow release and accumulation of the drug at the target site ${ }^{[16]}$ as a result of a longer circulation time, the release of the small molecule implies that renal excretion is mostly evident. Covalent albumin-binding can both, improve on the drug circulation time as well as facilitate tumour delivery and retention there in through the EPReffect $^{[15]}$ but the drug is not easily released and the excretion mechanism would be that of a larger, lipophilic construct through the liver.

The accumulation of activity in the liver of the $\left[{ }^{64} \mathrm{Cu}\right] \mathrm{Cu}-\mathrm{GluCAB}$ maleimide-1 injected mice could also possibly have been as a result of two processes: firstly, a loss of the copper(II) ions from the chelator complex in the blood stream followed by subsequent binding of the ionic copper to serum proteins and delivery to the liver for further processing; or secondly, transchelation of the copper from the GluCAB complex to a copper-dependent enzyme, e.g., superoxide dismutase (SOD), that is highly abundant in liver cells. ${ }^{[48]}$ Although cyclam chelates have shown high in vivo stability and resistance to transchelation by SOD, it has also been noted that conjugation to biomolecules could alter this stability and this should be kept in mind for $\left[{ }^{64} \mathrm{Cu}\right] \mathrm{Cu}$-GluCAB.

Biodistribution Studies. The image-guided quantification matched the illustrated distribution behaviour of the compounds with the normalised organ activity concentration (SUV) for $\left[{ }^{64} \mathrm{Cu}\right] \mathrm{Cu}-\mathrm{TETA}, \quad\left[{ }^{64} \mathrm{Cu}\right] \mathrm{Cu}-\mathrm{GluCAB}$-amine-2 and $\left[{ }^{64} \mathrm{Cu}\right] \mathrm{Cu}-$ GluCAB-maleimide-1 provided first such results. Following the last image acquisition, the post mortem biodistribution analysis quantifies the precise amount of radioactivity per organ allowing herein the robust comparison of the ${ }^{64} \mathrm{Cu}$-labelled compounds as illustrated in Figure 5.

As already indicative from $24 \mathrm{~h}$ MIP image in Figure 4A, very low ${ }^{64} \mathrm{Cu}$-activity amounts were obtained for $\left[{ }^{64} \mathrm{Cu}\right] \mathrm{Cu}$-TETA; indeed all organs showed negligible TETA levels ex vivo (on average $0.20 \pm 0.06 \% \mathrm{ID} / \mathrm{g}$ ) with the only notable radioactivity found in the kidneys $(0.37$ and $0.40 \% \mathrm{ID} / \mathrm{g})$. No notable difference between the activity in the organs of mice injected with $\left[{ }^{64} \mathrm{Cu}\right] \mathrm{Cu}$-TETA and $\left[{ }^{64} \mathrm{Cu}\right] \mathrm{Cu}$-GluCAB-amine-2 was observed - except for a 6-fold higher $\left[{ }^{64} \mathrm{Cu}\right] \mathrm{Cu}$-GluCAB-amine-2 presence within the large intestine $(2.31 \% \mathrm{ID} / \mathrm{g})$ and 2.5 -fold higher $\left[{ }^{64} \mathrm{Cu}\right] \mathrm{Cu}-\mathrm{GluCAB}-a m i n e-2$ hepatic presence $(0.91$ $\% \mathrm{ID} / \mathrm{g})$. This confirms the excretion patterns and conclusions drawn from the microPET/CT image analysis. The $\left[{ }^{64} \mathrm{Cu}\right] \mathrm{Cu}-$ TETA and $\left[{ }^{64} \mathrm{Cu}\right] \mathrm{Cu}-\mathrm{GluCAB}$-amine-2 compounds were rapidly eliminated from the system through the renal and hepatobiliary pathways, respectively. The biodistribution analysis of $\left[{ }^{64} \mathrm{Cu}\right] \mathrm{Cu}$ GluCAB-maleimide-1 mice recorded the maximum ${ }^{64} \mathrm{Cu}$-activity in the plasma $(10.7 \pm 1.8 \% \mathrm{ID} / \mathrm{g})$ and the liver $(9.6 \pm 1.4 \% \mathrm{ID} / \mathrm{g})$ with the activity in all the other organs being $<4 \% \mathrm{ID} / \mathrm{g}$. Therefore, the activity of $\left[{ }^{64} \mathrm{Cu}\right] \mathrm{Cu}-\mathrm{GluCAB}$-maleimide-1 in all the organs was significantly different ( $p<0.05$ or less) as compared to that of $\left[{ }^{64} \mathrm{Cu}\right] \mathrm{Cu}$-TETA and $\left[{ }^{64} \mathrm{Cu}\right] \mathrm{Cu}$-GluCAB-amine-2 except for the large intestines indicating similar $\left[{ }^{64} \mathrm{Cu}\right] \mathrm{Cu}-\mathrm{GluCAB}$ amine-2 levels. These results were in-line with observations from the image-guided biodistribution for $\left[{ }^{64} \mathrm{Cu}\right] \mathrm{Cu}$-GluCABmaleimide-1, which remains in circulation (i.e. bound to plasma proteins, such as seen for HSA) as indicated by a $\sim 45$ to 55 -fold higher presence in plasma $(10.7 \pm 1.8 \% \mathrm{ID} / \mathrm{g})$ as compared to $\left[{ }^{64} \mathrm{Cu}\right] \mathrm{Cu}$-TETA $(0.25 \pm 0.16 \% \mathrm{ID} / \mathrm{g} ; \mathrm{p}<0.001)$ and $\left[{ }^{64} \mathrm{Cu}\right] \mathrm{Cu}-$ GluCAB-amine-2 $(0.19 \% \mathrm{ID} / \mathrm{g})$. Consequently, all other organs also show significantly higher activity levels compared to TETA, in particular the liver uptake of $9.60 \pm 1.36 \% \mathrm{ID} / \mathrm{g}$ for GluCABmaleimide-1, which was 25 -fold higher than TETA $(p<0.001)$, therefore confirming the hepatobiliary excretion pathway expected for larger protein based compounds. The liver, being a highly perfused organ, also reflects any remaining blood pool ${ }^{64} \mathrm{Cu}$-activity, which is possible for other organs as well; the $\% \mathrm{ID} / \mathrm{g}$ of the heart $(3.15 \pm 2.13)$ was similar to that of the lung $(3.21 \pm 1.03)$ and twice as high to that of the spleen (1.33 \pm 0.30 ). Also, notable uptake (with reference to muscle tissue $(0.57 \pm 0.10 \% \mathrm{ID} / \mathrm{g}))$, was seen in ovaries and stomach. Interestingly, while the ${ }^{64} \mathrm{Cu}$-activity in the large intestines was similar between $\left[{ }^{64} \mathrm{Cu}\right] \mathrm{Cu}-\mathrm{GluCAB}$-maleimide-1 and -amine-2, the $\left[{ }^{64} \mathrm{Cu}\right] \mathrm{Cu}$-GluCAB-maleimide-1 levels were 4-fold higher than -amine-2 within the small intestinal tract (Figure 5). 


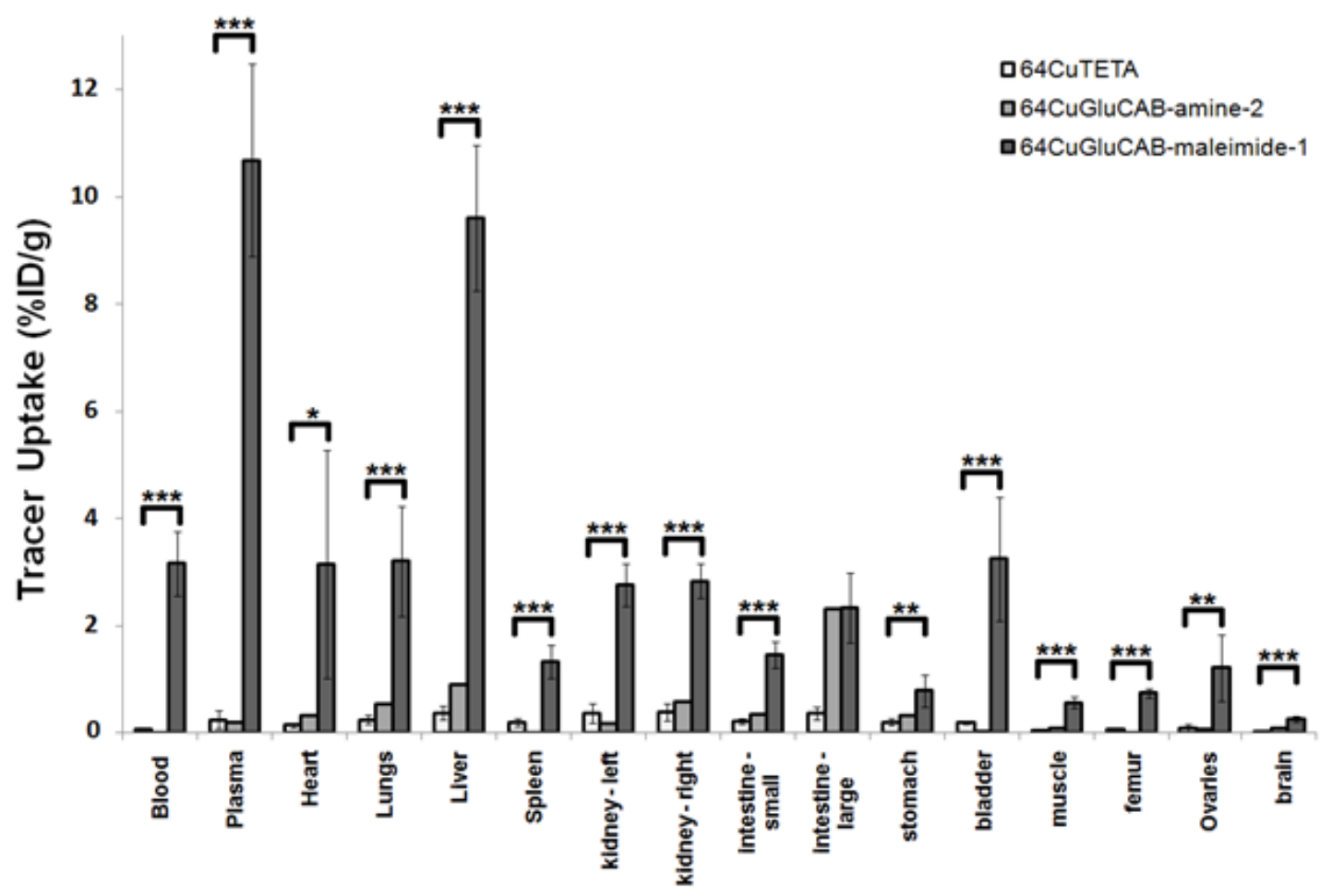

Figure 5. Comparison of ex vivo biodistribution at $24 \mathrm{~h}$ after injection of $\left[{ }^{64} \mathrm{Cu}\right] \mathrm{Cu}-\mathrm{TETA}(\mathrm{n}=5)$, $\left[{ }^{64} \mathrm{Cu}\right] \mathrm{Cu}-\mathrm{GluCAB}-\mathrm{amine}-2$ ( $\left.\mathrm{n}=1\right)$ and $\left[{ }^{64} \mathrm{Cu}\right] \mathrm{Cu}-\mathrm{GluCAB}-\mathrm{malemide-1}$ $(n=5)$ presented as mean \%ID/g $\pm S D)$; two-tailed Student's t-test comparing radiolabelled TETA with GluCAB-malemide-1 returned $p<0.05\left({ }^{*}\right)$, $p<0.01\left({ }^{* *}\right)$ or $p$ $\left.<0.001{ }^{(* \star *}\right)$.

\section{Conclusion}

Herein, the first and second phase of a potentially new radioligand designed for tumour-targeting and theranostic capabilities has been completed. The bifunctional chelator, GluCAB-maleimide-1, has been successfully synthesized, radiolabelled and preliminarily investigated for its in vivo albumin-binding. Towards this end, GluCAB-amine-2 was successfully radiolabelled with copper-64 and subsequently converted to its radiolabelled GluCAB-maleimide-1 derivative, which proved to be very stable in serum. In vivo studies for $\left[{ }^{64} \mathrm{Cu}\right] \mathrm{Cu}$-GluCAB-maleimide-1 clearly estimated a prolonged biological half-life $(6-8 \mathrm{~h})$ as compared to the pharmacokinetics of $\left[{ }^{64} \mathrm{Cu}\right] \mathrm{Cu}$-GluCAB-amine-2 (lacking the maleimide functionality), and although an elevated liver uptake was noted, an adequate compound excretion was seen within $24 \mathrm{~h}$. These results have translational merit for continuation to phase 3 of the investigation - the evaluation of $\left[{ }^{64} \mathrm{Cu}\right] \mathrm{Cu}$-GluCAB-maleimide-1 towards tumour targeting in diseased animal models. However, this study had some limitations which need to be considered such as 1) the high temperature and low $\mathrm{pH}$ conditions required for chelator radiolabelling that are not compatible with the sensitive maleimide functional group; and 2) the increased liver uptake - possibly as a result of the complex charge, complex instability in vivo or SOD transchelation within the liver. Further studies are under way addressing these limitations, and, once accomplished, tumour targeting using $\left[{ }^{64} \mathrm{Cu}\right] \mathrm{Cu}-\mathrm{GluCAB}-\mathrm{PET} / \mathrm{CT}$ imaging can be established.

\section{Experimental Section}

Synthesis and characterisation of GluCAB-amine-2 and GluCABmaleimide-1.The full chemical synthesis of all the compounds described in the text can be found in the Supporting Information. Described below is the synthetic method (and characterisation) for compounds (1) and (2) via the protected intermediate compound (3) and synthesised components (4), (5) and (6) (Scheme 1). All commercial chemical reagents and solvents were purchased from Sigma Aldrich Chemical Co. Ltd or Merck (South Africa). Thin layer chromatography was carried out on Silica-gel $60 \mathrm{~F}_{254}$ plates (Art. 5554; Merck).Column chromatography was done using Silica-gel 60 from (Merck 7734, 0.040-0.063 mm). Melting points were determined on a Reichert-Jung Thermovar hot-stage microscope. Infrared spectra were recorded on a Perkin Elmer Spectrum 100 FT-IR Spectrometer using $\mathrm{NaCl}$ disks for oils or $\mathrm{KBr} /$ compound discs for solids. High-resolution mass spectra were obtained on a Agilent 6530 Accurate-Mass Q-TOF LC/MS with electrospray ionization (ESI) using an Agilent 1290 HPLC fitted with Agilent Eclipse Plus C18 RRHD 1.8 micron $2.1 \times 50 \mathrm{~mm}$ column. ${ }^{1} \mathrm{H}$ NMR and ${ }^{13} \mathrm{C}$ NMR were recorded on a Varian Mercury $300 \mathrm{MHz}\left(75.5 \mathrm{MHz}\right.$ for $\left.{ }^{13} \mathrm{C}\right)$, a Varian Unity $\left(400 \mathrm{MHz}\right.$ for ${ }^{13} \mathrm{C}$ ) or a Bruker Advance III with Ultra Shield 400 Plus magnet.All spectra were recorded in deuterated chloroform or deuterated water and all chemical shifts were recorded in ppm with reference to the resonance of the residual solvent used as internal standard. For radiolabelling, all solvents used were HPLC grade from Merck and all buffer solutions were prepared using common procedures with Milli-Q grade water $(>18$ $\mathrm{M} \Omega / \mathrm{cm})$. The activity of the $\left[{ }^{64} \mathrm{Cu}\right] \mathrm{CuCl}_{2}$ solution was measured using a Capintec CRC-15R gamma detector (Capintec Inc., Florham Park, NJ, USA). All radiolabelled compounds were analysed by radio-HPLC analysis on Varian Prostar 325 UV-Vis HPLC apparatus (Varian Inc, Walnut Creek, CA, USA) fitted with a radiometric GABI Star gamma detector (raytest $\mathrm{GmbH}$, Straubenhardt, Germany) using a Zorbax Stable Bond-C18 column $(5 \mu \mathrm{m} ; 4.6 \times 250 \mathrm{~mm})$ with a gradient elution over 20 min of $95-5 \% A$ in $B$ (Solvent $A=\mathrm{H}_{2} \mathrm{O}(0.1 \%$ TFA); Solvent $B=M e C N$ 
$(0.1 \%$ TFA $))$. Purification of the radiolabelled products was done using a pre-conditioned Sep-Pak Light C-18 cartridge (Waters Corporation, Milford, MA, USA). For in vitro and in vivo studies, samples were centrifuged using a Hettich EBA 20 (A. Hettich GmbH \& Co, Tuttlingen, Germany) and automated gamma counting was done using Hidex AMG (LabLogic, Turku, Finland). Serum separation was done using BD Vacutainer $\left(\right.$ SST $^{\mathrm{TM}}$ serum separator tubes (Becton, Dickinson and Company (Franklin Lakes, NJ, USA).

1-[10-(2,3,4,6-O-tetrabenzoyl- $\beta, D-$ glucopyranos-1-yl)-1-oxodecyl]4,11-Bis-( $t$-butoxycarbonylmethyl)-8-(10-( $t$-butoxycarbonylamino)decyl)-1,4,8,11-tetraazacyclotetradecane (3). Cyclam (5) $(0.290$ g, 0.49 $\mathrm{mmol})$ was reacted with glycosyl bromide $(4)(0.280 \mathrm{~g}, 0.34 \mathrm{mmol})$ and $\mathrm{K}_{2} \mathrm{CO}_{3}(0.204 \mathrm{~g}, 1.47 \mathrm{mmol})$ in $\mathrm{MeCN}(20 \mathrm{~mL})$ to yield 1-[10-( $\beta, \mathrm{D}-$ glucopyranos-1-yl)-1-oxodecyl]-4,11-Bis-( $t$-butoxycarbonylmethyl)1,4,8,11-tetraazacyclotetradecane (15) as a clear oil following purification $(0.233 \mathrm{~g}, 58 \%)$ (See supporting information for full reaction and characterisation).

Alkyl bromide (6) $(0.115 \mathrm{~g}, 0.34 \mathrm{mmol})$ was dissolved in MeCN (1 mL) and added to a solution of cyclam (15) $(0.200 \mathrm{~g}, 0.17 \mathrm{mmol})$ in MeCN (10 $\mathrm{mL}$ ) along with $\mathrm{K}_{2} \mathrm{CO}_{3}(0.071 \mathrm{~g}, 0.51 \mathrm{mmol})$. The solution was stirred at $80{ }^{\circ} \mathrm{C}$ for $16 \mathrm{~h}$ followed by filtration through a small celite pad which was then washed with MeCN $(2 \mathrm{~mL})$. The filtrate was concentrated down to leave an oily reside which was purified using column chromatography $\left(\mathrm{CH}_{2} \mathrm{Cl}_{2}\right.$ : $\mathrm{MeOH}: \mathrm{NH}_{4} \mathrm{OH}, 8.8: 1.1$ : 0.1$)$. Some product remained on the column and was flushed out with $\mathrm{CH}_{2} \mathrm{Cl}_{2}$ : $\left.\mathrm{MeOH}: \mathrm{NH}_{4} \mathrm{OH}, 7: 2.5: 0.5\right)$. Compound (3) was obtained as a clear oil $(0.176 \mathrm{~g}, 74 \%) ; \mathrm{R}_{f}=0.56$ $\left(\mathrm{CH}_{2} \mathrm{Cl}_{2}: \mathrm{MeOH}: \mathrm{NH}_{4} \mathrm{OH}, 8.8: 1.1: 0.1\right) ; \delta_{\mathrm{H}}\left(\mathrm{CDCl}_{3}, 300 \mathrm{MHz}\right): 8.01-7.81$ $(8 \mathrm{H}, \mathrm{m}, \mathrm{ArH}), 7.55-7.25(12 \mathrm{H}, \mathrm{m}, \mathrm{ArH}), 5.89(1 \mathrm{H}, \mathrm{t}, J=9.6 \mathrm{~Hz}, \mathrm{H}-3 \mathrm{Glu})$ $5.66(1 \mathrm{H}, \mathrm{t}, J=9.6 \mathrm{~Hz}, \mathrm{H}-4 \mathrm{Glu}), 5.50(1 \mathrm{H}, \mathrm{dd}, J=7.8,9.6 \mathrm{~Hz}, \mathrm{H}-2 \mathrm{Glu})$, $4.83(1 \mathrm{H}, \mathrm{d}, J=7.8 \mathrm{~Hz}, \mathrm{H}-1 \mathrm{Glu}), 4.62(1 \mathrm{H}, \mathrm{dd}, J=3.2,12.0 \mathrm{~Hz}, \mathrm{H}-$ 6aGlu), $4.50(2 \mathrm{H}, \mathrm{dd}, J=5.2,12.0 \mathrm{~Hz}, \mathrm{H}-6 \mathrm{bGlu},-\mathrm{NH}), 4.14(1 \mathrm{H}, \mathrm{m}, \mathrm{H}-$ $5 \mathrm{Glu}), 3.89\left(1 \mathrm{H}, \mathrm{dt}, J=6.4,9.6 \mathrm{~Hz}, \mathrm{OCH}_{2}\right), 3.53(1 \mathrm{H}, \mathrm{dt}, J=6.8,9.6 \mathrm{~Hz}$, $\left.\mathrm{OCH}_{2}\right), 3.38\left(4 \mathrm{H}, \mathrm{bs},-\mathrm{NCH}_{2}\right), 3.19-2.94\left(18 \mathrm{H}, \mathrm{bm},-\mathrm{NCH}_{2}\right), 2.78-2.68(4 \mathrm{H}$ bm, - $\left.\mathrm{NCH}_{2}\right), 1.98\left(4 \mathrm{H}, \mathrm{bm}, \mathrm{NCH}_{2} \mathrm{CH}_{2} \mathrm{CH}_{2} \mathrm{~N}\right), 1.67\left(4 \mathrm{H}, \mathrm{bm}, \mathrm{CH}_{2}\right), 1.50$ $\left(2 \mathrm{H}, \mathrm{m}, \mathrm{CH}_{2}\right), 1.43\left(27 \mathrm{H}, \mathrm{s}, \mathrm{CH}_{3}\right), 1.34-1.01\left(26 \mathrm{H}, \mathrm{m}, \mathrm{CH}_{2}\right.$-alk); $\delta \mathrm{c}\left(\mathrm{CDCl}_{3}\right.$, $100 \mathrm{MHz}): 170.8(\mathrm{C}=\mathrm{O}), 170.8(\mathrm{C}=\mathrm{O}),[166.2,165.9,165.2,165.0$ $(\mathrm{C}=\mathrm{O})], 156.5(\mathrm{C}=\mathrm{O}),[133.4,133.2,133.2,133.1(\mathrm{ArC})],[129.9(\mathrm{x} 2), 129.8$ (x2), $129.6(x 2), 129.0(x 2), 128.6,128.5(x 2), 128.4(x 2), 128.3,128.1$ (x2) ( $\mathrm{ArC})], 101.3(\mathrm{C}-1 \mathrm{Glu}), 81.1(\mathrm{C}-\mathrm{B} \mathrm{Bu}), 81.1\left(\mathrm{C}-{ }^{\mathrm{t}} \mathrm{Bu}\right), 80.5$ (C-'Bu), 73.0 (C-3Glu), 72.2 (C-2Glu), 72.0 (C-5Glu), $70.4\left(\mathrm{OCH}_{2}\right), 69.9$ (C-4Glu), 63.3 (C-6Glu), $56.1\left({ }^{(} \mathrm{CH}_{2} \mathrm{COO}\right), 56.1\left(\mathrm{C}_{2} \mathrm{COO}\right)$, [53.9, 51.8, 51.3 (x2), 51.2 (x2), 50.7 (x2), 49.3 (x2)(C-N)],40.9 ( $\left.\mathrm{CH}_{2} \mathrm{NHCO}\right)$, [29.8, 29.7, 29.4 (x2), 29.4 (x2), 29.3 (x4), $29.2(x 2), 28.2(x 2)\left(\mathrm{CH}_{3}\right), 28.1\left(\mathrm{CH}_{3}\right), 27.2(\mathrm{x} 2), 25.8$, 25.7, 24.8, $\left.23.7\left(\mathrm{CH}_{2} \mathrm{Alk} / \mathrm{NCH}_{2} \mathrm{CH}_{2} \mathrm{CH}_{2} \mathrm{~N}\right)\right] ; v_{\max } / \mathrm{cm}^{-1}: 1733(\mathrm{C}=\mathrm{O})$ HRMS (ESI MALDI-TOF): $\mathrm{m} / \mathrm{z}$ Calculated for $\mathrm{C}_{81} \mathrm{H}_{119} \mathrm{~N}_{5} \mathrm{O}_{16}(\mathrm{M})^{+}$; 1417.8652 found - mass too large, could not be determined.

1-[10-( $\beta, D-$ glucopyranos-1-yl)-1-oxodecyl]-8-(10-aminodecyl)-4,11diacetic acid-1,4,8,11-tetraaza-cyclotetradecane (2). Removal of the benzoyl protecting groups from the glycoside of compound (3) was done as follows: Sodium methoxide $(25 \%$ in $\mathrm{MeOH})(0.5 \mathrm{~mL})$ was added to a solution of (3) $(0.100 \mathrm{~g}, 0.07 \mathrm{mmol})$ in anh. $\mathrm{MeOH}(4 \mathrm{~mL})$ and stirred for $1 \mathrm{~h}$. The reaction was quenched by addition of Dowex $\mathrm{H}+$ to a $\mathrm{pH}$ of 5 and stirred for $15 \mathrm{~min}$. Following work-up and purification (see supporting information), 1-[10-(B,D-glucopyranos-1-yl)-1-oxodecyl]-4,11-Bis-( $t$ butoxycarbonylmethyl)-8-(10-( $t$-butoxycarbonylamino)decyl)-1,4,8,11tetraazacyclotetradecane (16) was obtained as a clear oil $(0.050 \mathrm{~g}, 71 \%)$.

Cyclam (16) $(0.050 \mathrm{~g}, 0.05 \mathrm{mmol})$ was dissolved in a mixture of $\mathrm{CH}_{2} \mathrm{Cl}_{2}$ : TFA $(1: 1 ; 4 \mathrm{~mL})$ and stirred for $16 \mathrm{~h}$ at RT. The solvent was evaporated under a stream of air and the oily residue redissolved in $10 \% \mathrm{NH}_{4} \mathrm{OH}$ in water $(1 \mathrm{~mL})$. The product was purified with column chromatography using Alumina $\mathrm{N}$ as the stationary phase. The mobile phase for elution of the by-products consisted of a gradient elution with $\mathrm{DCM}: \mathrm{MeOH}: \mathrm{NH}_{4} \mathrm{OH}$ (8:1.7:0.3; $7: 2.5: 0.5 ; 6.5: 3: 0.5)$ while the product was eluted with $\mathrm{MeOH}: \mathrm{H}_{2} \mathrm{O}(6: 4 ; 4: 6)$. The combined product fractions were concentrated under a stream of air overnight. The residue was redissolved in water $(0.5 \mathrm{~mL})$ and desalted by loading onto a Sep-Pak Light C-18 cartridge, washing the cartridge with water $(2 \mathrm{~mL})$ and then eluting the product with $50 \% \mathrm{MeOH}$ in water $(2 \mathrm{~mL})$. The solvent was evaporated off under a stream of argon, the residue redissolved in water $(1 \mathrm{~mL})$ and freeze-dried (Christ Alpha 1-5, Type 1050, Medizinische Apparatebau, Harz, Germany) overnight to yield the title compound, GluCAB-amine-2 as a lyophilised powder $(0.027 \mathrm{~g}, 69 \%)$. $\delta \mathrm{H}(\mathrm{D} 2 \mathrm{O}, 300 \mathrm{MHz}): 4.34(1 \mathrm{H}, \mathrm{d}, \mathrm{J}=$ $7.8 \mathrm{~Hz}, \mathrm{H}-1 \mathrm{Glu}), 3.80$ (2H, m, OCH2, H-6aGlu), 3.63-3.56 (4H, m, OCH2, $\mathrm{H}$-6bGlu, -NCH2), 3.49-3.25 (6H, m, H-2/3/4/5Glu, - NCH2), 3.202.85(16H, bm, - $\mathrm{NCH} 2), 2.70-2.60(6 \mathrm{H}, \mathrm{bm},-\mathrm{NCH} 2), 1.79(4 \mathrm{H}, \mathrm{bm}$, $\mathrm{NCH} 2 \mathrm{CH} 2 \mathrm{CH} 2 \mathrm{~N}), 1.60-1.50(8 \mathrm{H}, \mathrm{bm}, \mathrm{CH} 2), 1.29-1.15(24 \mathrm{H}, \mathrm{m}, \mathrm{CH} 2$ alk) $\delta$ C(D2O, $100 \mathrm{MHz}$ ): $173.8(\mathrm{C}=\mathrm{O}), 173.7(\mathrm{C}=\mathrm{O}), 102.0$ (C-1Glu), 75.8 (C-3Glu), 75.7 (C-2Glu), 73.1 (C-5Glu), 70.6 (OCH2), 69.6 (C-4Glu), 60.7 (C-6Glu), 54.6 (CH2COO), 54.5 (CH2COO ), [54.0, 52.5, 51.6, 51.5, 50.6 (x2), 50.0 (x2), 49.6, 49.4 (C-N)], 41.4 (CH2NHCO), [30.8, 30.7, 30.6 (x2), 30.4 (x2), 30.3 (x2), 30.0, 29.2, 28.7, 28.0, 27.8, 27.6, 25.8, 25.7, 22.5, 21.3 (CH2Alk/NCH2CH2CH2N)]; vmax/ cm-1: $3345(\mathrm{OH} / \mathrm{NH})$, 1688 (C=O)HRMS (ESI MALDI-TOF): $\mathrm{m} / \mathrm{z}$ Calculated for $\mathrm{C} 40 \mathrm{H} 79 \mathrm{~N} 5 \mathrm{O} 10$ $(\mathrm{M}+\mathrm{H})+; 790.5860 ;$ found 790.5887

4-[10-(4-(2,5-dioxo-2,5-dihydro-1 H-pyrrol-1-yl)butanamido)decyl]-11[10-( $\beta, D-$ glucopyranos-1-yl)-1-oxodecyl]-1,4,8,11-

tetraazacyclotetradecane-1,8-diacetic acid (1). Maleimido-butyric acid NHS-ester $(0.005 \mathrm{~g}, 0.017 \mathrm{mmol})$ was dissolved in DMF $(0.05 \mathrm{~mL})$ and added to a solution of GluCAB-amine-2 $(0.010 \mathrm{~g}, 0.011 \mathrm{mmol})$ in $0.01 \mathrm{M}$ PBS $(0.40 \mathrm{~mL} ; \mathrm{pH} 7.4)$. The reaction was stirred for $1.5 \mathrm{~h}$ at room temperature followed by evaporation of solvent under an air stream. The residue was redissolved in water $(0.20 \mathrm{~mL})$ and loaded onto a Sep-Pak Light C-18 cartridge pre-conditioned with $\mathrm{EtOH}(4.0 \mathrm{~mL})$ and water $(2.0$ $\mathrm{mL})$. The cartridge was fractionally eluted with water $(2 \times 2 \mathrm{~mL}), 10 \%$ $\mathrm{EtOH} /$ water $(2 \times 1 \mathrm{~mL}), 20 \% \mathrm{EtOH} /$ water $(4 \times 0.5 \mathrm{~mL})$ and $30 \%$ $\mathrm{EtOH} /$ water $(10 \times 0.5 \mathrm{~mL})$. The fractions of $30 \% \mathrm{EtOH} /$ water were combined and dried under argon to yield the GluCAB-maleimide-1 0.006 g, 55\%) $\delta \mathrm{H}\left(\mathrm{D}_{2} \mathrm{O}, 300 \mathrm{MHz}\right): 6.78(2 \mathrm{H}, \mathrm{s}, \mathrm{CHMal}), 4.32(1 \mathrm{H}, \mathrm{d}, J=7.8$ $\mathrm{Hz}, \mathrm{H}-1 \mathrm{Glu}), 3.86\left(2 \mathrm{H}, \mathrm{m}, \mathrm{OCH}_{2} \mathrm{a}, \mathrm{H}-6 \mathrm{GGlu}\right), 3.65-3.56\left(4 \mathrm{H}, \mathrm{m}, \mathrm{OCH}_{2} \mathrm{~b}\right.$ $\left.\mathrm{H}-6 \mathrm{bGlu},-\mathrm{NCH}_{2}\right), 3.52\left(2 \mathrm{H}, \mathrm{m}, \mathrm{OCCH}_{2} \mathrm{CH}_{2} \mathrm{CH}_{2} \mathrm{NMal}\right), 3.49-3.25(6 \mathrm{H}, \mathrm{m}$, $\left.\mathrm{H}-2 / 3 / 4 / 5 \mathrm{Glu},-\mathrm{NCH}_{2}\right), 3.20-2.85\left(16 \mathrm{H}, \mathrm{bm},-\mathrm{NCH}_{2}\right), 2.70-2.60(6 \mathrm{H}, \mathrm{bm}$, $\left.\mathrm{NCH}_{2}\right), \quad 2.17\left(2 \mathrm{H}, \quad \mathrm{m}, \quad \mathrm{OCCH}_{2} \mathrm{CH}_{2} \mathrm{CH}_{2} \mathrm{NMal}\right), \quad 1.87 \quad(2 \mathrm{H}, \quad \mathrm{m}$, $\left.\mathrm{OCCH}_{2} \mathrm{CH}_{2} \mathrm{CH}_{2} \mathrm{NMal}\right), 1.79\left(4 \mathrm{H}, \mathrm{bm}, \mathrm{NCH}_{2} \mathrm{CH}_{2} \mathrm{CH}_{2} \mathrm{~N}\right), 1.62-1.50(8 \mathrm{H}$ bm, $\left.\mathrm{CH}_{2}\right), 1.29-1.15\left(24 \mathrm{H}, \quad \mathrm{m}, \quad \mathrm{CH}_{2}\right.$-alk); $\delta \mathrm{c}\left(\mathrm{D}_{2} \mathrm{O}, 100 \mathrm{MHz}\right): 174.8$ $(\mathrm{C}=\mathrm{O}), 173.8(\mathrm{C}=\mathrm{O}), 173.7(\mathrm{C}=\mathrm{O}), 172.4(\mathrm{C}=\mathrm{OMal}), 134.5(\mathrm{C}=\mathrm{C}), 102.2$ (C-1Glu), 75.9 (C-3Glu), 75.8 (C-2Glu), 73.3 (C-5Glu), $70.8\left(\mathrm{OCH}_{2}\right), 69.9$

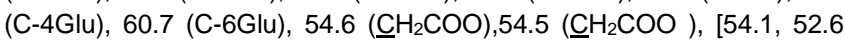
51.6, 51.6, 50.5 (x2), 50.1 (x2), 49.7, 49.4 (C-N)], 40.4 ( $\left.\mathrm{CH}_{2} \mathrm{NHCO}\right), 38.1$ (C-4), 34.2 (C-2), [30.8, 30.7, 30.6 (x2), 30.4 (x2), 30.3 (x2), 30.0, 29.2, 28.7, 28.0, 27.8, 27.6, 25.8, 25.7, 25.6, 22.5, 21.3 $\left(\mathrm{CH}_{2} \mathrm{Alk} / \mathrm{NCH}_{2} \mathrm{C}_{2} \mathrm{CH}_{2} \mathrm{~N}\right)$ ]; HRMS (ESI MALDI-TOF): $\mathrm{m} / \mathrm{z}$ Calculated for $\mathrm{C}_{48} \mathrm{H}_{86} \mathrm{~N}_{6} \mathrm{O}_{13}(\mathrm{M}+\mathrm{H})^{+} ;$955.6286; found 955.6291

Isotope Preparation. All solutions and buffers were prepared using common procedures using Milli-Q grade water (>18 M $\Omega / \mathrm{cm})$. Copper-64 was obtained by irradiation of a CuO (Sigma-Aldrich; $99.9999 \%$ purity) powder target $(1 \mathrm{mg})$ for $36 \mathrm{~h}$ in the 'in-core' position with a neutron flux of $1 \times 10^{14} \mathrm{n} / \mathrm{cm}^{2} / \mathrm{s}$ ( $8 \mathrm{~h}$ cooling period) at the SAFARI-1 research reactor (Necsa, Pelindaba, South Africa). The irradiated copper oxide powder was dissolved in $\mathrm{C}$. $\mathrm{HCl}(50 \mu \mathrm{L})$ and diluted with water $(950 \mu \mathrm{L})$ to produce a solution of $\left[{ }^{64} \mathrm{Cu}\right] \mathrm{CuCl}_{2}$. Gamma spectrometry (Canberra Germanium Detector - GC2518 (24\% deficiency) (Mirion Technologies, Canberra; Inc. CT, USA) confirmed presence of the characteristic 511 $\mathrm{keV}$ and $1345 \mathrm{keV}$, emissions of copper-64.

Radiolabelling. To establish the optimal conditions for radiolabelling of GluCAB-amine-2 with ${ }^{64} \mathrm{Cu}$ the radiolabelling performance was compared at $\mathrm{pH} 3.5,5.0$ and 9.0 , at temperatures of $45,70,80$ and $90{ }^{\circ} \mathrm{C}$ and reaction times of 10,20 and $30 \mathrm{~min}$, respectively. Purification of the radiolabelled products was done using a pre-conditioned $(4 \mathrm{~mL} \mathrm{EtOH}$ followed by $2 \mathrm{~mL} \mathrm{H}_{2} \mathrm{O}$ ) Sep-Pak Light $\mathrm{C}-18$ cartridge by loading the 
reaction solution on the cartridge, washing with water $(2 \mathrm{~mL})$ and eluting the labelled product with $50 \% \mathrm{EtOH} / \mathrm{H}_{2} \mathrm{O}(1 \mathrm{~mL})$.

${ }^{64}$ Cu-Radiolabelling - Optimized Method. A $\left[{ }^{64} \mathrm{Cu}\right] \mathrm{CuCl}_{2}$ solution (100 $\mu \mathrm{L} ;$ 10-12 MBq; molar equivalent ligand: metal = 3:1) was added to the GluCAB-amine-2 in $0.1 \mathrm{M} \mathrm{NH}_{4} \mathrm{OAc}$ buffer $(100 \mu \mathrm{L} ; 10 \mathrm{mg} / \mathrm{mL} ; \mathrm{pH} 5.5)$. The $\mathrm{pH}$ of the solution was adjusted with $0.1 \mathrm{M} \mathrm{NaOH}(60 \mu \mathrm{L})$ to $\mathrm{pH} 3.5$, the vial capped and the solution heated for $30 \mathrm{~min}$ at $90{ }^{\circ} \mathrm{C}$ (Table S1). After the solution had cooled it was purified on a SPE cartridge as indicated. The reaction solution was dried under a stream of argon with heating $\left(60^{\circ} \mathrm{C}\right)$, the residue was re-dissolved in $0.01 \mathrm{M}$ PBS $(400 \mu \mathrm{L})$ and radio-HPLC analysis performed.

Post-labelling Conversion of $\left[{ }^{64} \mathrm{Cu}\right] \mathrm{Cu}$-GluCAB-amine-2 to [ $\left.{ }^{64} \mathrm{Cu}\right] \mathrm{Cu}$ GluCAB maleimide-1. 4-maleimidobutyric acid NHS-ester $(4.5 \mu \mathrm{L}, 100$ $\mu \mathrm{g} / \mu \mathrm{L}$ in DMF, $1.3 \mathrm{eq})$ was added to the $\left[{ }^{64} \mathrm{Cu}\right] \mathrm{Cu}-\mathrm{GluCAB}-a m i n e-2$ reaction vial (400 $\mu \mathrm{L}, 0.01 \mathrm{M}$ PBS) and stirred for $1 \mathrm{~h}$ at room temperature. The reaction solution $(400 \mu \mathrm{L})$ was purified on a SPE cartridge as described above, dried under argon with slight heating (60 $\left.{ }^{\circ} \mathrm{C}\right)$ and redissolved in $0.01 \mathrm{M}$ PBS.

${ }^{64}$ Cu-Radiolabelling for in vivo Studies. A $\left[{ }^{64} \mathrm{Cu}\right] \mathrm{CuCl}_{2}$ solution $(60 \mu \mathrm{L}$; $0.72 \mu \mathrm{mol}, 91.5 \mathrm{MBq}$ ) was added to a solution of GluCAB-amine-2 in 0.1 $\mathrm{M} \mathrm{NH}{ }_{4} \mathrm{OAc}$ buffer $(177 \mu \mathrm{L} ; 2.24 \mu \mathrm{mol} ; 10 \mathrm{mg} / \mathrm{mL})$. The $\mathrm{pH}$ of the solution was adjusted to $\mathrm{pH} 3.5$ using $2 \mathrm{M} \mathrm{NaOH}(4 \mu \mathrm{L})$, the vial capped and the solution heated for $30 \mathrm{~min}$ at $90{ }^{\circ} \mathrm{C}$. Purification was done as mentioned above. The dried $\left[{ }^{64} \mathrm{Cu}\right] \mathrm{Cu}-\mathrm{GluCAB}-$ amine-2 (labelling efficiency of $97 \%$ ) was redissolved in $0.01 \mathrm{M}$ PBS $(900 \mu \mathrm{L})$ for in vivo application. The production of the maleimide compound included the following steps: After purification, the dried $\left[{ }^{64} \mathrm{Cu}\right] \mathrm{Cu}-\mathrm{GluCAB}$-amine-2 was redissolved in 0.01 M PBS $(400 \mu \mathrm{L})$ and 4-maleimidbutyric acid NHS-ester $(9 \mu \mathrm{L}, 100 \mu \mathrm{g} / \mu \mathrm{L}$ in $\mathrm{DMF}, 1.2 \mathrm{eq})$ was added to the reaction vial. The reaction was stirred for $1 \mathrm{~h}$ at room temperature followed by SPE purification as indicated and drying under a stream of argon with heating $\left(60^{\circ} \mathrm{C}\right)$. The residue was redissolved in $0.01 \mathrm{M}$ PBS $(900 \mu \mathrm{L})$ thereby providing $\left[{ }^{64} \mathrm{Cu}\right] \mathrm{Cu}-\mathrm{GluCAB}$ maleimide-1 (93\% conversion, $90 \%$ overall yield).

The radiolabelling for the TETA (control compound) was done in a similar manner: $\left[{ }^{64} \mathrm{Cu}\right] \mathrm{CuCl}_{2}$ solution $(60 \mu \mathrm{L} ; 0.72 \mu \mathrm{mol}, 91.5 \mathrm{MBq})$ was added to a solution of TETA in $0.1 \mathrm{M} \mathrm{NH}_{4} \mathrm{OAc}$ buffer $(150 \mu \mathrm{L} ; 1.61 \mu \mathrm{mol}$; ligand: metal 2:1). The $\mathrm{pH}$ of the solution was adjusted with $2 \mathrm{M} \mathrm{NaOH}(1 \mu \mathrm{L})$ to $\mathrm{pH} 3.5$, the vial capped and the solution heated for $30 \mathrm{~min}$ at $90^{\circ} \mathrm{C}$. The product was purified, dried and redissolved in 0.01 M PBS. A labelling efficiency of $95 \%$ and radiochemical purity of $99 \%$ was obtained.

Stability and Protein Binding Studies. The in vitro stability and serum protein binding studies of $\left[{ }^{64} \mathrm{Cu}\right] \mathrm{Cu}-\mathrm{GluCAB}$-amine-2 and $\left[{ }^{64} \mathrm{Cu}\right] \mathrm{Cu}$ GluCAB-maleimide-1 were completed according to a method previously described. ${ }^{[49]}$ Briefly, the stability was evaluated by adding the desired compound (50 $\mu \mathrm{L}, \sim 10 \mathrm{MBq}$ ) to serum $(1 \mathrm{~mL})$ and incubating the solution at $37^{\circ} \mathrm{C}$. Samples $(100 \mu \mathrm{L})$ were drawn at $0,1,2,18$ and $24 \mathrm{~h}$ after addition of compound and the proteins precipitated by the addition of cold acetonitrile $(500 \mu \mathrm{L})$. The samples were centrifuged for $10 \mathrm{~min}$ at 6000 $\mathrm{rpm}$ and the supernatant collected, diluted with MilliQ water and analysed by radio-HPLC (conditions as above). The protein binding was evaluated by addition of the desired compound $(25 \mu \mathrm{L}, \sim 5 \mathrm{MBq})$ to serum $(450 \mu \mathrm{L})$ and incubation of the solution at $37^{\circ} \mathrm{C}$. Samples $(100 \mu \mathrm{L})$ were drawn at $0,1,2$ and $24 \mathrm{~h}$ after administration and the proteins precipitated by the addition of cold acetonitrile $(500 \mu \mathrm{L})$. The samples were centrifuged for $10 \mathrm{~min}$ at $6000 \mathrm{rpm}$ and the supernatant was separated from the protein pellet which was then washed again with acetonitrile $(100 \mu \mathrm{L})$. The activity of the pellet and supernatant (combined with the wash) was then measured using automated gamma counting and decay-corrected for all samples. The protein binding is expressed as a percentage of the total activity measured.

Small Animal PET/CT Imaging. The animal studies were planned and conducted in accordance with the national regulation for the use of laboratory animals for research purposes (SANS 10386). The research was approved by the nationally registered North-West University Animal Care, Health and Safety Research Ethics Committee, (NWU-AnimCare; NWU-00379-16-A5). Female balb/c mice (age: $6-8$ weeks; weight: $26 \pm 3$ g) obtained from the North West University, Preclinical Drug Development Platform (PCDDP) Vivarium (Potchefstroom, South Africa) were housed in individually ventilated cages (Techniplast IVC, Buguggiate, Italy) (ad libitum access to water and food, $12 \mathrm{~h}$ light/dark cycles and sterile corn-cob bedding). The animals were acclimatised at the Pre-Clinical Imaging Facility (Pelindaba, South Africa) for 1 week prior to commencement of the study. Imaging studies were performed using the small animal PET/CT camera (nanoScanPET/CT, Mediso Medical Imaging Systems, Budapest, Hungary). Mice were randomised and allocated to one of three groups $(n=5)$ as following: $A)\left[{ }^{64} \mathrm{Cu}\right] \mathrm{Cu}$ TETA, B) $\left[{ }^{64} \mathrm{Cu}\right] \mathrm{Cu}$-GluCAB-amine-2 or C) $\left[{ }^{64} \mathrm{Cu}\right] \mathrm{Cu}-\mathrm{GluCAB}$-maleimide1. The compounds, as indicated per group, were administered intravenously via the lateral tail vein. The animals were anaesthetised using a mix of isoflurane in oxygen (3-4\% for induction and $2-2.5 \%$ for maintenance). MicroPET/CT image acquisition (CT scan: time $-5 \mathrm{~min}$, method - semi-circular, zoom - max FOV, binning - 1:4 and image reconstruction: voxel size -medium, filter type - Cosine; PET scan: time 20 min, coincidence mode - 1-5, prone-head first position) were performed at 1, 2 and 24 after injection for group A and B and at 1, 2, 4, 8 and $24 \mathrm{~h}$ after injection for Group C using the Nucline software (Mediso Ltd, Budapest, Hungary). Qualitative and quantitative analysis was performed on decay-, scatter-, randoms- and attenuation- corrected images using InterView Fusion software (Mediso Ltd, Budapest, Hungary). PET images were normalized (low 0.0; high 10.0) to allow for comparison between different time points and between the three compounds. Image-guided tissue quantification, i.e. activity concentration in blood pool (heart) as well as in other organs was done by creating tissue-specific, CT-guided volume-of-interest ('VOI's) areas and each VOI was used to determine the mean standardized uptake value (SUV) $(\mathrm{g} / \mathrm{mL})$.

Biodistribution. Following the imaging studies, the biodistribution of the ${ }^{64} \mathrm{Cu}$-compounds at $24 \mathrm{~h}$ p.i was determined as follows: animals were euthanized by decapitation and blood was immediately collected into a pre-weighed SST ${ }^{\mathrm{TM}}$ tubes; serum was yielded by centrifugation ( $5 \mathrm{~min}$; $6000 \mathrm{rpm})$. Other tissues and organs were collected into pre-weighed 6 $\mathrm{mL}$ plastic vials and the radioactivity of all the samples was measured using automated gamma counting. A standard dilution of the injected activity was performed measuring three volume fractions (100, 200 and $500 \mu \mathrm{L}$ ) to determine the counts/MBq. This value was then used to express the organ activity as a decay-corrected, percentage of the injected dose per gram of tissue $(\% / \mathrm{I} / \mathrm{g})$.

Statistics. The protein binding studies were done in triplicate and the data reported as the mean \pm standard deviation (SD). The standard uptake values (SUV) determined from microPET/CT analysis and the biodistribution data determined from gamma counting are presented as the mean values and standard deviation (SD). The significance between two mean values of interest was determined by using the two-tailed equal variance Student's $t$-test. The levels of significance (p) for validating the alternative hypothesis are established at $p<0.05,<0.01$ or $<0.001$

\section{Acknowledgements}

The authors acknowledge financial support by the South African Nuclear Energy Corporation (Necsa) and research funding provided by BGM Pharmaceuticals, South Africa. Further financial support and infrastructure is acknowledged for preclinical studies from the Nuclear Medicine Research Infrastructure (NuMeRI) NPC as funded by the Department of Science and Innovation (DSI), South Africa. M.I.P. was jointly 
supported by the SAMRC with funds received from the National Department of Health and the MRC UK with funds from the UK Government's Newton Fund and GSK. The authors would like to thank: Department of Chemistry (University of Cape Town) technical staff for assistance with NMR analysis and the Hunter Research Group for organic synthesis support; Ms M. Buys and Ms B. Marjanovic-Painter (Necsa) for assistance with isotope gamma analysis and HPLC/MS analysis; The staff at the PreClinical Drug Development Platform (PCDDP), NWU, Potchefstroom for assistance with in vivo studies and associated veterinary services; Ms D van Wyk (NuMeRI) and Dr. J. Kleynhans (NuMeRI) for assistance during microPET/CT imaging.

\section{Supporting Information}

Details provided include a complete synthesis and characterization of all compounds indicated in the main manuscript as well as radio-HPLC chromatograms for serum stability analysis of the ${ }^{64} \mathrm{Cu}$-labelled compounds.

\section{Conflict of Interest}

The authors declare no competing financial interest

Keywords: cancer • radiopharmaceuticals $\cdot$ macrocyclic ligands - copper-64 • albumin-binding

[1] G. Ting, C-H. Chang, H-E. Wang, T-W. Lee, J. Biomed. Biotech. 2010, Art ID: 953537.

[2] S. Van Zutphen, J. Reedijk, Coord. Chem. Rev. 2005, 249, 2845-2853.

[3] F C. Giancotti, FEBS Letters 2014, 588, 2558-2570.

[4] S. Acharya, S. K. Sahoo, Adv. Drug Deliv. Rev. 2011, 63, 170-183.

[5] a) H. Maeda, G.Y. Bharate, J. Daruwalla, Eur. J. Pharm. Biopharm. 2009, 71, 409-419; b) J. Fang, H. Nakamura, H. Maeda, Adv. Drug Deliv. Rev. 2011, 63, 136-151.

[6] a) Y. Matsumura, H. Maeda, Cancer Res. 1986, 46, 6387-6392; b) H. Maeda, Y. Matsumura, Crit. Rev. Ther. Drug Carrier Syst. 1989, 6, 193210; c) H. Maeda, Adv. Drug Deliv. Rev. 2001, 46, 169-185.

[7] a) D. Rosenblum, N. Joshi, W. Tao, J. M. Karp, D. Peer, Nat. Commun. 2018, 9, 1410; b) J. Kydd, R. Jadia, P. Velpurisiva, A. Gad, S. Paliwal, P. Rai, Pharmaceutics 2017, 9, 46.

[8] a) N. Bertrand, J. Wu, X. Xu, N. Kamaly, O.C. Farokhzad, Adv. Drug Deliv. Rev. 2014, 66, 2-25; b) K. Cho, X. Wang, S. Nie, Z. Chen, D. Shin, Clin. Cancer Res. 2008, 14, 1310-13016.

[9] C.F. Ramogida, C. Orvig, Chem. Commun. 2013, 49, 4720-4739.

[10] S. Liu, Adv. Drug Deliv. Rev. 2008, 60, 1347-1370.

[11] Z. Liu, X. Chen, Chem. Soc. Rev. 2016, 45, 1432-1456.

[12] A. O. Elzoghby, W. M. Samy, N. A. Elgindy, J. Control. Release. 2012, 157, 168-182.

[13] a) F. Kratz, J. Control. Release. 2008, 132, 171-183; b) F. Kratz, G. Ehling, H. M. Kauffmann, C. Unger, Hum. Exp. Toxicol. 2007, 26, 1935.

[14] E. Miele, G. P. Spinelli, E. Miele, F. Tomao, Int. J. Nanomed. 2009, 4, 99-105.

[15] O. Jacobson, D. O. Kiesewetter, X. Chen, Bioconjugate Chem. 2016, 27, 2239-2247.

[16] J. Lau, O. Jacobson, G. Niu, K.-S. Lin, F. Bénard, X. Chen, Bioconjugate Chem. 2019, 30, 487-502.

[17] C. Müller, R. Farkas, F. Borgna, R. M. Schmid, M. Benešová, R. Schibli, Bioconjugate Chem. 2017, 28, 2372-2383.
[18] M. Upadhyay, J. Samal, M. Kandpal, O. V. Singh, P. Vivekanakdan, Pharmacol. Ther. 2013, 137, 318-330.

[19] R. L. Wahl, J. Nucl. Med. 1996, 37, 1038-1041.

[20] 14 T. A. Smith, Nucl. Med. Comm. 1998, 19, 97-105.

[21] G. R. Morais, R. A. Falconer, I. Santos, Eur. J. Org. Chem. 2013, 2013, 1401-1414.

[22] H. Feng, X. Wang, J. Chen, J. Cui, T. Gao, Y. Gao, W. Zeng, Contrast. Media. Mol. Imaging. 2019, 2019, 7954854.

[23] M. Zhang, Z. Zhang, D. Blessington, H. Li, T. M. Busch, V. Madrak, J Miles, B. Chance, J. D. Glickson, G. Zheng, Bioconjug. Chem. 2003 14, 709-714.

[24] R. Schibli, C. Dumas, J. Petrig, L. Spadola, L. Scapozza, E. GarciaGarayoa, P. A. Schubiger, Bioconjug. Chem. 2005, 16, 105-112.

[25] J. Weber, L. Bollepalli, A. M Belenguer, M. Di Antonio, N. De Mitri, J. Joseph, S. Balasubramanian, C. A. Hunter, S. E. Bohndiek Cancer Res. August 27 2019, DOI: 10.1158/0008-5472.CAN-19-0691

[26] a) X. Liang, P. J. Sadler, Chem. Soc. Rev. 2004, 33, 246-266; b) C. Y. Ke, C. J. Mathias, M. A. Green, Adv. Drug Deliv. Rev. 2004, 56, 11431160.

[27] T. M. Hunter, S. J. Paisey, H-S. Park, L. Cleghorn, A. Parkin, S. Parsons, P. J. Sadler, J. Inorg. Biochem. 2004, 98, 713-719.

[28] T. J. Hoffmann, C. J. Smith, Nucl. Med. Biol. 2009, 36, 579-585.

[29] M. Galibert, Z-H. Jin, T. Furukawa, T. Saga, Y. Fujibayashi, P. Dumy, D. Boturyn, Bioorg. Med. Chem. Lett. 2010, 20, 5422-5425.

[30] B. Gutfelin, S.A.L. Souza, G. Valentini, Drug Des. Devel. Ther. 2018, 12, 3235-3245.

[31] X. Sun, C.J. Anderson, Methods Enzymol. 2004, 386, 273-261.

[32] A. R. Jalilian, J. Osso, Iran. J. Nucl. Med. 2017, 25, 1-10.

[33] M. Paurova, T. David, I. Cisarova, P. Lubal, P. Hermann, J. Kotek, New J. Chem. 2018, 42, 11908-11929.

[34] T. J. Wadas, E. H. Wong, G. R. Weisman, C. J. Anderson, Cur. Pharm. Design. 2007, 13, 3-16.

[35] P. Szymanski, T. Fraczek, M. Markowicz, E. Mikiciuk-Olasik, Biometals. 2012, 25, 1089-1112.

[36] T. Murakami, Y. Sato, M. Shibakami, Carbohydr. Res. 2008, 343, 12971308.

[37] a) J. Thiem, B. Meyer, Chem. Ber. 1980, 113, 3075-3085; b) J. Gervay, T. N. Nguyen, M. J. Hadd, Carbohydr. Res. 1997, 300, 119-125.

[38] K. Siwowska, S. Haller, F. Bortoli, M. Benesova, V. Groehn, P. Bernhardt, R. Schibli, C. Muller, Mol. Pharmaceutics. 2017, 14 523-532.

[39] a) D. N. Pandya, J. Y. Kim, J. C. Park, H. Lee, P. B. Phapale, W. Kwak, T. H. Choi, G. J. Cheon, Y-R. Yoon, J. Yoo, Chem. Commun. 2010, 46, 3517-3519; b) D. N. Pandya, A. V. Dale, J. Y. Kim, H. Lee, Y. S. Ha, G. I. An, J. Yoo, Bioconjug. Chem. 2012, 23, 330-335.

[40] D. N. Pandya, N. Bhatt, A. V. Dale, J. Y. Kim, H. Lee, Y. S. Ha, J-E. Lee, G. II An, J. Yoo Bioconjug. Chem. 2013, 24, 1356-1366.

[41] K. V. Vimalnath, A. Rajeswari, V. Chirayil, P. L. Sharad, K. C Jagadeesan, P. V. Joshi, M. Venkatesh, J. Radioanal. Nucl. Chem. 2011, 290, 221-225

[42] International Atomic Energy Agency, in: IAEA radioisotopes and radiopharmaceuticals reports no. 1. IAEA, Vienna, 2016, pp. 3-7

[43] Q. Xie, H. Zhu, F. Wang, X. Meng, Q. Ren, C. Xia, Z. Yang, Molecules 2017, 22, 641.

[44] J. D. Silversides, C. C. Allan, S. J. Archibald, Dalton Trans. 2007, 9, $971-978$.

[45] T. M. Jones-Wilson, K. A. Deal, C. J. Anderson, D. W. McCarthy, Z. Kovacs, R. J. Motekaitis, A. D. Sherry, A. E. Martell, M. J. Welch, Nucl. Med. Biol. 1998, 25, 523-530.

[46] S. K. Bardal, J. E. Waechter, D. S. Martin in Applied Pharmacology; Chapter 2: Pharmacokinetics, St Louis, Mo: Elsevier/Saunders, 2011, pp 17-34.

[47] D. G. Levitt, M. D. Levitt, Int. J. Gen. Med. 2016, 9, 229-255.

[48] K. Zarschler, M. Kubeil, H. Stephan, RSC Adv. 2014, 4, 10157-10164.

[49] W. Beaino, C. J. Anderson, J. Nucl. Med. 2014, 55, 1856-1863. 


\section{Entry for the Table of Contents}

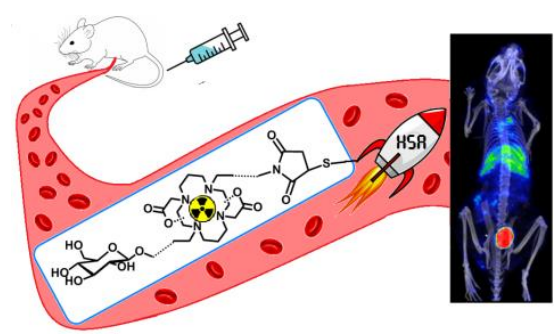

GluCAB is a newly synthesised radioligand designed to bind in vivo to albumin (HSR) for the purpose of development as a dualtargeting oncological theranostic agent. Subsequent to its synthesis and ${ }^{64} \mathrm{Cu}$-radiolabelling, this radioligand has show a prolonged circulation time in healthy mice but with appropriate systemic clearance within $24 \mathrm{~h}$. This radioligand met the criteria to be further investigated for tumour targeting and uptake. 